\title{
Unit Costs of Waste Management Operations
}

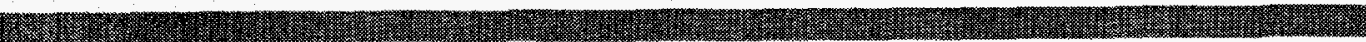

by W.E. Kisieleski, S.M. Folga, J.L. Gillette, and W.A. Buehring

Center for Cost Engineering,

Decision and Information Sciences Division,

Argonne National Laboratory, 9700 South Cass Avenue, Argonne, Illinois 60439

April 1994

Work sponsored by United States Department of Energy,

Office of Environmental Management

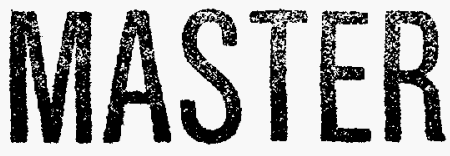




\section{DISCLAIMER}

This report was prepared as an account of work sponsored by an agency of the United States Government. Neither the United States Government nor any agency thereof, nor any of their employees, make any warranty, express or implied, or assumes any legal liability or responsibility for the accuracy, completeness, or usefulness of any information, apparatus, product, or process disclosed, or represents that its use would not infringe privately owned rights. Reference herein to any specific commercial product, process, or service by trade name, trademark, manufacturer, or otherwise does not necessarily constitute or imply its endorsement, recommendation, or favoring by the United States Government or any agency thereof. The views and opinions of authors expressed herein do not necessarily state or reflect those of the United States Government or any agency thereof. 


\section{DISCLAIMER}

Portions of this document may be illegible in electronic image products. Images are produced from the best available original document. 


\section{CONTENTS}

ACKNOWLEDGMENTS $\ldots \ldots \ldots \ldots \ldots \ldots \ldots \ldots \ldots \ldots \ldots \ldots \ldots \ldots$ vii

NOMENCLATURE $\ldots \ldots \ldots \ldots \ldots \ldots \ldots \ldots \ldots \ldots \ldots \ldots \ldots \ldots \ldots \ldots$

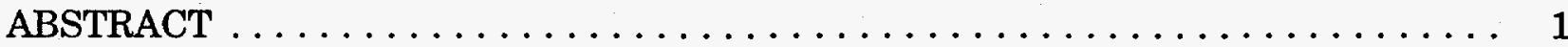

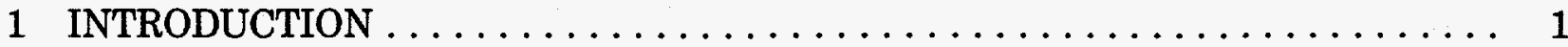

1.1 Purpose and Scope $\ldots \ldots \ldots \ldots \ldots \ldots \ldots \ldots \ldots \ldots \ldots \ldots \ldots \ldots \ldots \ldots$

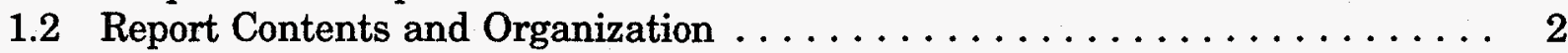

2 WASTE AND ITS MANAGEMENT $\ldots \ldots \ldots \ldots \ldots \ldots \ldots \ldots \ldots$

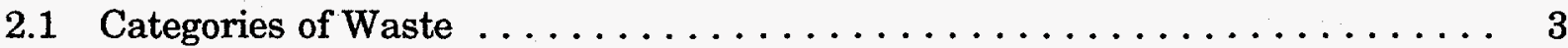

2.2 Waste Management Practices . . . . . . . . . . . . . . . . . . 4

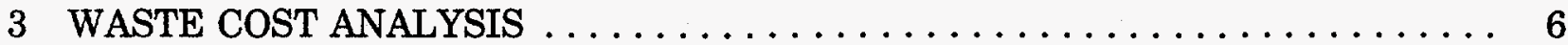

4 RADIOACTIVE WASTE $\ldots \ldots \ldots \ldots \ldots \ldots \ldots \ldots \ldots \ldots \ldots \ldots$

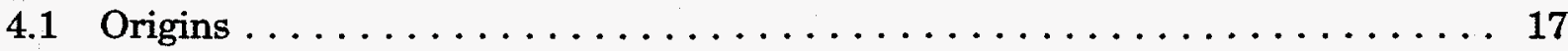

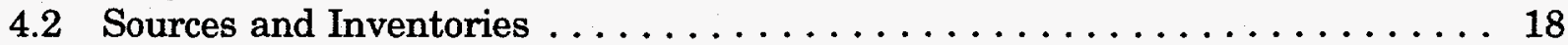

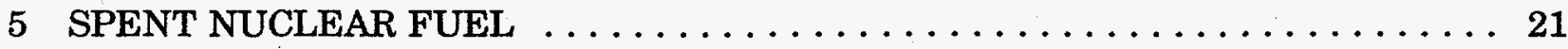

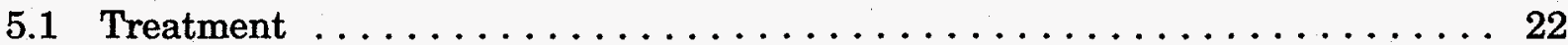

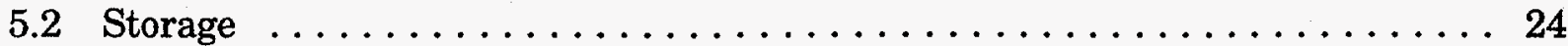

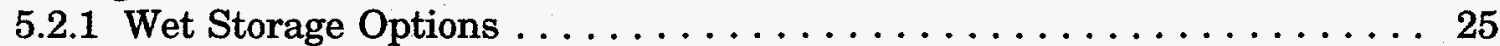

5.2 .1 .1 Reracking ........................ 25

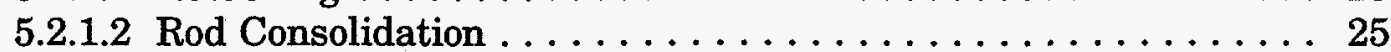

5.2.1.3 Water Basins . . . . . . . . . . . . . . . . . . 28

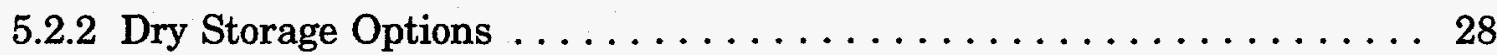

5.2.2.1 Transportable Metal Casks . . . . . . . . . . . . . 28

5.2 .2 .2 Concrete Modules . . . . . . . . . . . . . . . . . 29

5.2 .2 .3 Modular Vaults . . . . . . . . . . . . . . . . . 29

5.3 Disposal ............................... 30

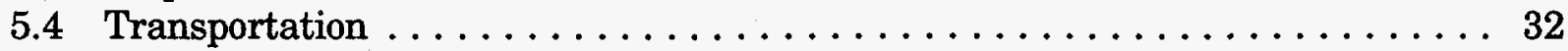

6 HIGH-LEVEL WASTE $\ldots \ldots \ldots \ldots \ldots \ldots \ldots \ldots \ldots \ldots \ldots \ldots \ldots \ldots \ldots$

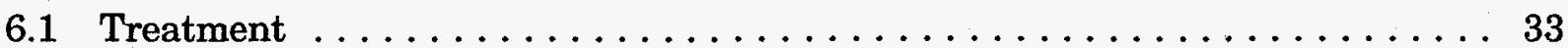

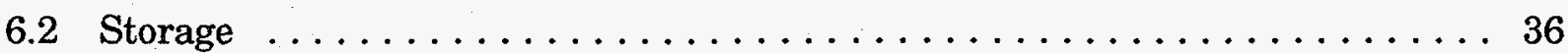

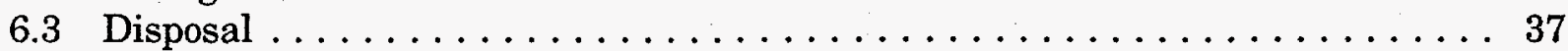

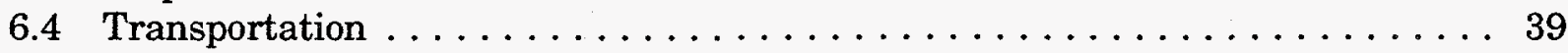


7 LOW-LEVEL WASTE $\ldots \ldots \ldots \ldots \ldots \ldots \ldots \ldots \ldots \ldots \ldots \ldots \ldots$

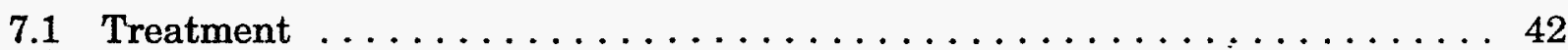

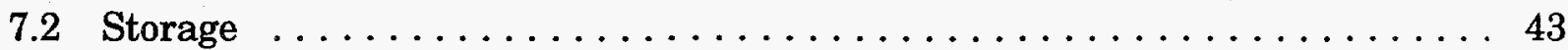

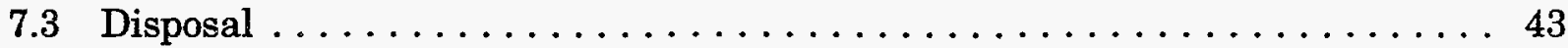

7.4 Transportation $\ldots \ldots \ldots \ldots \ldots \ldots \ldots \ldots \ldots \ldots \ldots \ldots \ldots \ldots \ldots$

8 TRANSURANIC WASTE $\ldots \ldots \ldots \ldots \ldots \ldots \ldots \ldots \ldots \ldots \ldots \ldots \ldots$

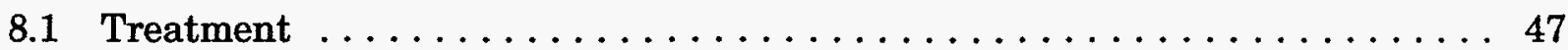

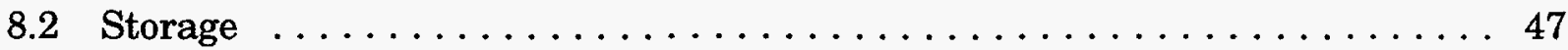

8.3 Disposal . . . . . . . . . . . . . . . . . . . . . . 49

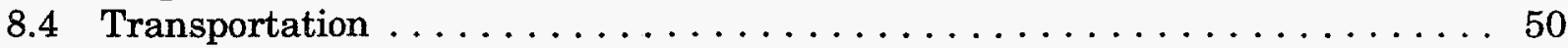

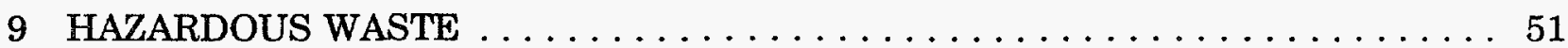

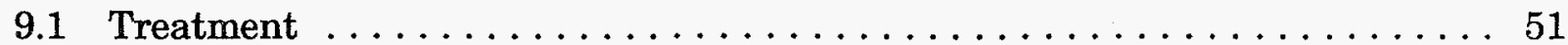

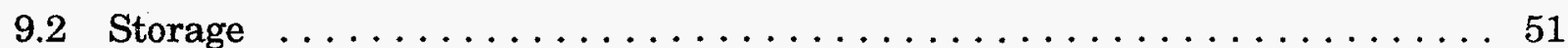

9.3 Disposal . . . . . . . . . . . . . . . . . . . . . . . 52

9.4 Transportation ......................... 52

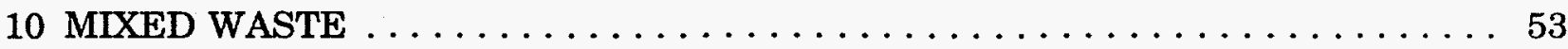

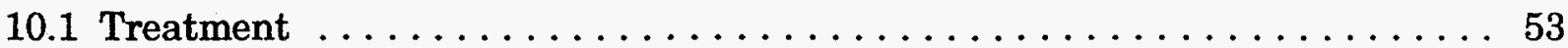

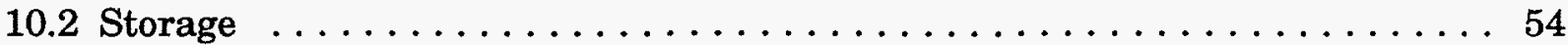

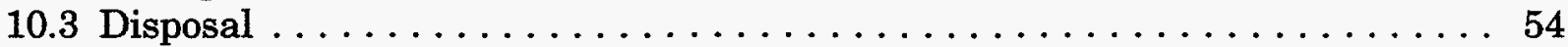

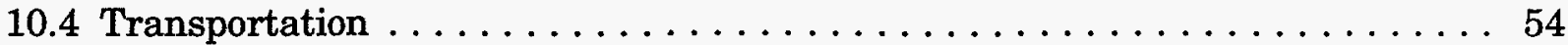

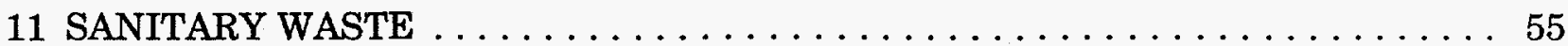

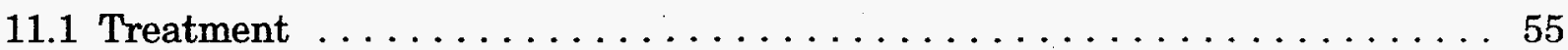

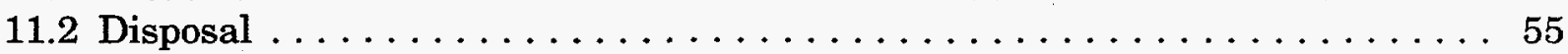

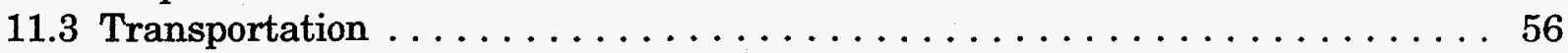

12 SUMMARY AND CONCLUSIONS $\ldots \ldots \ldots \ldots \ldots \ldots \ldots \ldots \ldots \ldots$

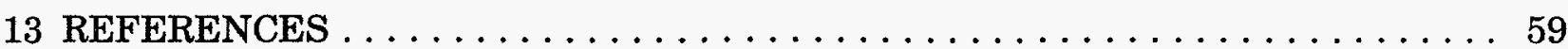

\section{TABLES}

1 Unit Costs for Management of Spent Nuclear Fuel $\ldots \ldots \ldots \ldots \ldots \ldots \ldots$

2 Unit Costs for Management of High-Level Waste $\ldots \ldots \ldots \ldots \ldots$

3 Unit Costs for Management of Low-Level Waste $\ldots \ldots \ldots \ldots \ldots \ldots$ 


\section{TABLES (Cont.)}

4 Unit Costs for Management of Transuranic Waste ................. 10

5 Unit Costs for Management of Hazardous Waste $\ldots \ldots \ldots \ldots \ldots \ldots \ldots \ldots$

6 Unit Costs for Management of Mixed Waste $\ldots \ldots \ldots \ldots \ldots \ldots \ldots \ldots \ldots$

7 Unit Costs for Management of Sanitary Waste $\ldots \ldots \ldots \ldots \ldots \ldots \ldots \ldots$

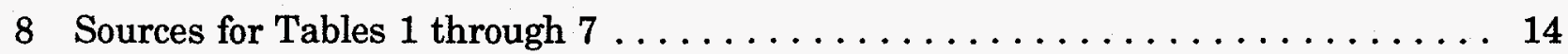

9 Total Volume of Commercial and DOE Wastes and Spent Nuclear Fuel through $1991 \ldots \ldots \ldots \ldots \ldots \ldots \ldots \ldots \ldots \ldots \ldots \ldots \ldots \ldots \ldots$

10 Total Radioactivity of Commercial and DOE Wastes and Spent

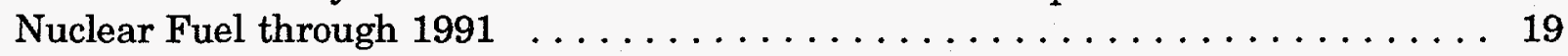

11 Projected Volume of Commercial and DOE Wastes and Spent

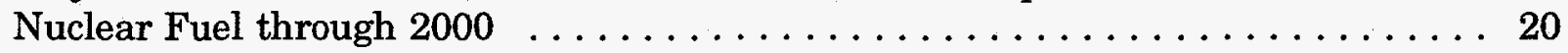

12 Projected Radioactivity of Commercial and DOE Wastes and Spent

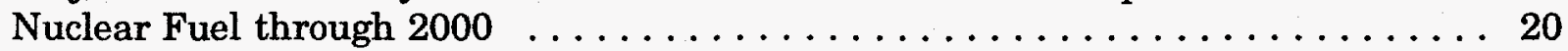

13 Unit Costs for Treatment of Spent Nuclear Fuel as a Function of Treatment Capacity .............................. 23

14 Unit Costs for Storage of Spent Nuclear Fuel as a Function of

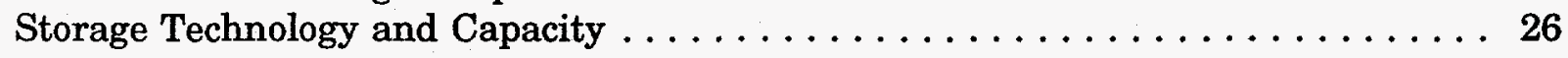

15 Unit Costs for Disposal of Spent Nuclear Fuel as a Function of Number of Repositories

16 Capital and Annual Operating Costs for Treatment of High-Level Waste at the Savannah River Site . . . . . . . . . . . . . . . . . 34

17 Unit Costs for Treatment of High-Level Waste at Various DOE Sites . . . . . . . 35

18 Unit Costs for Storage of High-Level Waste at the Three Main DOE Sites

19 Unit Costs for Disposal of High-Level Waste as a Function of Number of Repositories

20 Total Number of Canister-Miles for Transportation of High-Level Waste

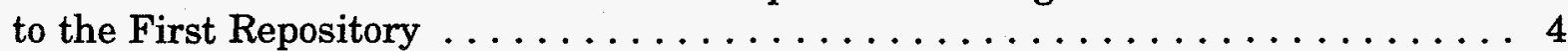




\section{FIGURES}

1 Unit Costs for Treatment of Spent Nuclear Fuel $\ldots \ldots \ldots \ldots \ldots \ldots$

2 Unit Costs for Storage of Spent Nuclear Fuel in Wet Storage Pools: Reracking and Rod Consolidation

3 Unit Costs for Storage of Spent Nuclear Fuel in Water Basins and Modular Vaults

4 Unit Costs for Storage of Spent Nuclear Fuel in Horizontal Concrete Vaults and Metal Storage Casks

5 Unit Costs for Storage and Disposal of Low-Level Waste

6 Unit Costs for Storage and Disposal of Transuranic Waste . . . . . . . . . . . 48

7 Unit Costs for Storage of Transuranic Waste in Concrete-Reinforced, Above-Grade, Shielded Facilities

8 Unit Costs for Storage and Disposal of Mixed Waste 


\section{ACKNOWLEDGMENTS}

The authors thank the many individuals in and outside the government agencies for their cooperation and contribution to the final report. Their suggestions and inputs have been appreciated. It is also our pleasure to thank members of Argonne National Laboratory, including Marita Moniger, who improved the format and language of the report through her careful editing; Michele Szawars, who provided graphics; and Document Processing Center staff, who assisted in the final publication of the report. We are also deeply indebted to the Office of Environmental Management of the U.S. Department of Energy for its continuing support of these efforts. 


\section{ACRONYMS, INITIALISMS, AND ABBREVIATIONS}

$\alpha \mathrm{MW}$

BOY

BWR

$\mathrm{CH}$

D\&E

DOE

DST

DWPF

EPA

FY

GAO

HAZW

HM

HLW

HWVP

IHM

INEL

LANL

LLW

LWR

MRF

MW

NRC

NUHOMS

NWPA

ORNL

PCB

PWR

RCRA

RH alpha-emitting mixed waste

beginning-of-year

boiling water reactor

contact-handled

development and evaluation U.S. Department of Energy double-shell tank Defense Waste Processing Facility

U.S. Environmental Protection Agency

fiscal year

U.S. General Accounting Office

hazardous waste heavy metal high-level waste Hanford Waste Vitrification Plant

initial heavy metal Idaho National Engineering Laboratory

Los Alamos National Laboratory

low-level waste

light water reactor

material recovery facility mixed waste

U.S. Nuclear Regulatory Commission Nutech horizontal storage module Nuclear Waste Policy Act of 1982

Oak Ridge National Laboratory

polychlorinated biphenyl pressurized water reactor

Resource Conservation and Recovery Act remote-handled 


$\begin{array}{ll}\text { SNF } & \text { spent nuclear fuel } \\ \text { SRS } & \begin{array}{l}\text { Savannah River Site } \\ \text { single-shell tank } \\ \text { sST }\end{array} \\ \text { SW } & \begin{array}{l}\text { transtary waste } \\ \text { total system life-cycle cost }\end{array} \\ \text { TRU } & \text { uranium } \\ \text { TSLCC } & \text { uranium oxide } \\ \mathrm{U} & \text { volume reduction factor } \\ \mathrm{UO}_{2} & \\ \text { VRF } & \text { Westinghouse Hanford Company } \\ \text { WHC } & \text { Waste Isolation Pilot Project }\end{array}$

\section{UNITS OF MEASURE}

\begin{tabular}{|c|c|}
\hline $\mathrm{Ci}$ & curie(s) \\
\hline $\begin{array}{l}\mathrm{ft} \\
\mathrm{ft}^{3}\end{array}$ & $\begin{array}{l}\text { foot (feet) } \\
\text { cubic foot (feet) }\end{array}$ \\
\hline $\begin{array}{l}\mathrm{g} \\
\text { gal }\end{array}$ & $\begin{array}{l}\text { gram(s) } \\
\text { gallon(s) }\end{array}$ \\
\hline $\mathrm{h}$ & hour(s) \\
\hline $\mathrm{kg}$ & kilogram(s) \\
\hline $\mathrm{lb}$ & pound(s) \\
\hline $\begin{array}{l}\mathrm{m}^{3} \\
\mathrm{mi} \\
\mathrm{mm} \\
\mathrm{mrem}\end{array}$ & $\begin{array}{l}\text { cubic meter(s) } \\
\text { mile(s) } \\
\text { millimeter(s) } \\
\text { milliroentgen equivalent man }\end{array}$ \\
\hline $\mathrm{nCi}$ & nanocurie $(\mathbf{s})\left(10^{-9}\right.$ curies $)$ \\
\hline rem & roentgen equivalent man \\
\hline $\begin{array}{l}t \\
\text { ton }\end{array}$ & $\begin{array}{l}\text { metric ton(s) }(2,200 \mathrm{lb}) \\
\text { short ton }(\mathrm{s})(2,000 \mathrm{lb})\end{array}$ \\
\hline $\begin{array}{l}\mathrm{yd}^{3} \\
\mathrm{yr}\end{array}$ & $\begin{array}{l}\text { cubic yard(s) } \\
\text { year(s) }\end{array}$ \\
\hline
\end{tabular}




\title{
UNIT COSTS OF WASTE MANAGEMENT OPERATIONS
}

\author{
by
}

\author{
W.E. Kisieleski, S.M. Folga, J.L. Gillette, and W.A. Buehring
}

\begin{abstract}
This report provides estimates of generic costs for the management, disposal, and surveillance of various waste types, from the time they are generated to the end of their institutional control. Costs include monitoring and surveillance costs required after waste disposal. Available data on costs for the treatment, storage, disposal, and transportation of spent nuclear fuel and high-level radioactive, low-level radioactive, transuranic radioactive, hazardous, mixed (low-level radioactive plus hazardous), and sanitary wastes are presented. The costs cover all major elements that contribute to the total system life-cycle (i.e., "cradle to grave") cost for each waste type. This total cost is the sum of fixed and variable cost components. Variable costs are affected by operating rates and throughput capacities and vary in direct proportion to changes in the level of activity. Fixed costs remain constant regardless of changes in the amount of waste, operating rates, or throughput capacities. Key factors that influence cost, such as the size and throughput capacity of facilities, are identified. In many cases, ranges of values for the key variables are presented. For some waste types, the planned or estimated costs for storage and disposal, projected to the year 2000 , are presented as graphics.
\end{abstract}

\section{INTRODUCTION}

\subsection{PURPOSE AND SCOPE}

Almost all industrial processes, whether they are conducted by the private or the public sector, produce some kind of solid or liquid wastes. In recent years, methods of treating, storing, transporting, and disposing of such wastes have come under increasingly acute public and regulatory scrutiny. Concerns have been related to a variety of issues including aesthetics, safety, risks, technologies, land use, and costs. In response to these concerns, many private and public institutions have undertaken programs for waste minimization, pollution prevention, risk assessment, land management, or technology research, development, and demonstration. An important element in the successful application of these programs is their impact on the overall cost of waste management and, in the private sector, on the cost of the final product resulting from the industrial process. Although many variables influence the costs of waste management activities, some 
representative estimates can be made for evaluating proposed waste management alternatives. Such evaluations can measure alternatives in terms of risk reduction per unit of cost, make straightforward cost comparisons, or simply estimate the impact of the different alternatives on product cost. The need for this type of evaluation led to the analysis discussed in this report.

\subsection{REPORT CONTENTS AND ORGANIZATION}

Seven generic waste types are considered in this report. They are spent nuclear fuel and high-level radioactive, low-level radioactive, transuranic radioactive, hazardous, mixed (hazardous plus low-level radioactive), and sanitary wastes. In some cases, there are subcategories of waste within the more general waste type. When cost data on the treatment, storage, disposal, and transportation of each waste type are applicable and available, they are provided. Costs of alternative techniques or processes are sometimes given. The information presented in this report reflects a "cradle to grave" approach, which considers all the components that can contribute to the cost of waste management, from the time waste is generated until the end of its institutional control.

Section 2 of this report briefly defines the seven waste types and provides some general comments on waste management. Section 3 summarizes the costs of each waste handling step (treatment, storage, disposal, and transportation) for each waste type. It contains tables that allow the reader to quickly find and compare cost estimates. Because several of the waste types are radioactive, Section 4 discusses the general nature of radioactive waste. Then each of Sections 5 through 11 focuses on one type of waste, presenting a detailed discussion of the waste and providing costs and descriptions of the treatment, storage, disposal, and transportation options considered in this report. 


\section{WASTE AND ITS MANAGEMENT}

Waste, whether it is from households or industry, is a natural part of everyday life. It is all around us, even when it cannot be seen, such as gaseous waste that has been released into the atmosphere. Waste is produced by every living thing and by most human endeavors. For example, the generation of electricity results in waste, no matter what the source of energy is: coal, oil, gas, or nuclear fuel. The production of nuclear weapons for national defense has also resulted in much of the waste that is currently the responsibility of the U.S. Department of Energy (DOE).

\subsection{CATEGORIES OF WASTE}

The waste types considered in this report are defined briefly here. The definitions consider the technical features and general characteristics of each category of waste. More details on each waste type are provided in Sections 5 through 11 of this report.

- Spent nuclear fuel (SNF) is the highly radioactive nuclear fuel discharged from a reactor. It can be stored at the reactor site and eventually placed in a repository without being reprocessed. SNF that is not reprocessed is considered high-level waste; thus, many of its management steps are similar to those for high-level waste.

- High-level waste (HLW) is radioactive waste that results from reprocessing SNF from nuclear reactors to recover uranium and plutonium. HLW contains transuranic elements and highly radioactive, heat-generating, and long-lived fission products. Management plans for liquid HLW usually specify that it be immobilized as a solid glass matrix and kept in interim storage facilities before final disposal and isolation in deep, stable geologic formations.

- Low-level waste ( $L L W)$ is radioactive waste that contains a negligible amount of long-lived radionuclides. LLW is divided into classes that require different treatment, storage, and disposal technologies. Produced by peaceful nuclear activities in industry, medicine, research, and nuclear power operations, such wastes can include items such as packaged gloves, rags, glass, small tools, paper, and filters that have been contaminated by radioactive material. The disposal of LLW in near-surface structures or the shallow burial of LLW are widely used practices.

- Transuranic (TRU) waste is radioactive waste that is not classified as HLW but is contaminated with alpha-emitting transuranic radionuclides with half-lives greater than 20 years and in concentrations greater than 100 nanocuries per gram ( $\mathrm{nCi} / \mathrm{g})$. This definition includes isotopes of 
neptunium ( $\mathrm{Np}$ ), plutonium $(\mathrm{Pu})$, americium $(\mathrm{Am})$, curium $(\mathrm{Cm})$, and californium (Cf). TRU waste is generated primarily during SNF reprocessing, plutonium recovery operations, and the manufacture of defense-related weapons.

- Hazardous waste (HAZW) is nonradioactive solid waste or a combination of solid wastes, which, because of its quantity, concentration, or physical, chemical, or infectious characteristics, may pose a potential hazard to people, property, or the environment unless properly managed. Solid waste, in this definition, includes any liquid, solid, semisolid, or contained gas.

- Mixed waste $(M W)$ is low-level radioactive waste that also contains a hazardous component. Management of MW must satisfy the requirements of both LLW and HAZW.

- Sanitary waste (SW) is nonradioactive and nonhazardous waste that is ultimately disposed of in a sanitary landfill.

\subsection{WASTE MANAGEMENT PRACTICES}

Waste management practices and techniques have been developed and implemented to safely and effectively handle the various categories of waste (American Nuclear Society . 1986; Duffy 1983). Waste management in this context can be defined as administrative or operational activities related to the minimization, handling, treatment, conditioning, transport, storage, and disposal of wastes. Although this definition may vary from country to country, scientists and engineers in the field agree that the overriding objective of waste management is to protect humans and the environment from the hazards arising from wastes, both now and in the future. The concern for the future arises because of the longlived radioactive components present in some types of waste, particularly HLW and SNF.

There are different approaches to waste management. The systems approach is the technique that was generally used to determine the cost estimates presented herein. It is a logical, integrated strategy for determining the requirements, technology, resources, and impacts of a waste management system. This approach considers each aspect of the entire system, from the waste's point of generation to its final disposal.

Handling waste from cradle to grave includes the actions listed below. Not all waste types are subjected to all of these actions.

- Waste sampling and analysis as required for sample characterization,

- Sorting,

- Segregation, 
- Size and volume reduction,

- Treatment,

- Posttreatment sample characterization of residuals to meet disposal criteria,

- Storage,

- Shipping and transport, and

- Final disposition.

The waste management process of treatment, storage, and disposal can be defined as follows. Treatment is any activity that alters the chemical or physical nature of a waste to reduce its toxicity, volume, or mobility or to render it amenable for transport, storage, or disposal. Storage is the retention and monitoring of waste in a retrievable form until it is put in final disposal. Disposal is the emplacement of waste that is designed to ensure its isolation from the biosphere. There is no intent to retrieve this waste in the foreseeable future; deliberate actions must be taken to regain access to the waste. 


\section{WASTE COST ANALYSIS}

Waste costs can be a very significant concern in any operation. Reaching sound management decisions on how to handle both radioactive and nonradioactive wastes requires a knowledge of waste life-cycle costs (DOE 1983, 1986a, 1990a). The total system life-cycle cost (TSLCC) includes all the cradle-to-grave costs - the costs incurred from the time the waste is generated to the end of its institutional control. In other words, the TSLCC includes all costs associated with waste handling, from its generation to its storage and treatment to its disposal and monitoring. Therefore, the waste operations (treatment, storage, disposal, and transportation) for which cost data are provided must be clearly defined for each waste type considered in this report.

Although this report does not describe in detail the analysis that went into the development of the life-cycle costs, it does both identify the cost factors typically included in this type of analysis and define the different cost categories (U.S. Environmental Protection Agency 1990). The major cost factors considered in any evaluation usually include capital cost; operating cost; cost for the monitoring, surveillance, and analysis of wastes and residuals; transportation cost; and disposal cost. Capital cost includes costs for designing and constructing the facilities and the cost of control systems, monitoring devices, localized instrumentation control, and support services. Operating cost includes costs for labor, maintenance, utilities, and materials and supplies. Sampling cost, which can also be significant, is not as clearly defined. It typically includes costs for conducting detailed sampling protocols and for chemical and radiochemical analysis and methodologies. Frequently the life-cycle cost of sampling is comparable to the total capital cost of the treatment facility.

Some cost-related terms must be understood to comprehend the development and significance of the overall costs reported herein. These terms include the following:

- Fixed costs remain constant regardless of changes in the amount of activity or volume of waste throughput.

- Variable costs vary in direct proportion to changes in the volume of waste throughput.

- Sunk costs have already been incurred, committed, or planned and are not affected by present or future waste generating rates.

- Relevant range is the span or quantity of waste throughput within which assumptions about fixed and variable costs are valid.

In estimating treatment, storage, disposal, and transportation costs, a distinction needs to be made between the terms "cost" and "price." A cost is an identifiable and accountable expense incurred in the production of a product or service. Price, on the other hand, is a result of the interaction of supply and demand forces in a market. The difference between price and cost can be simply understood by recognizing that the market reflects the vendors' costs plus the vendors' profit margin. 
Tables 1 through 7 present data on unit costs for the treatment, storage, disposal, and transportation of seven waste types: spent nuclear fuel and high-level, low-level, transuranic, hazardous, mixed, and sanitary waste. The data were obtained from documents and reports or personal communications with individuals responsible for these activities. Table 8 provides full information on these sources, which are simply referred to by number in Tables 1 through 7. To facilitate comparisons, normalization of the data was necessary, but it was largely limited to adjusting all costs to beginning-of-year (BOY) 1994 dollars. Escalation factors used for these adjustments were obtained from the Survey of Current Business (U.S. Department of Commerce 1994). Units of measurement given are generally those used in the sources. Further discussions of the data in these tables are provided in Sections 5 through 11.

TABLE 1 Unit Costs for Management of Spent Nuclear Fuel ${ }^{\mathrm{a}}$

\begin{tabular}{clll}
\hline Activity & \multicolumn{1}{c}{ Unit Cost } & \multicolumn{1}{c}{ Operation } & \multicolumn{1}{c}{ Source } \\
(see Table 8)
\end{tabular}

a Costs are given in beginning-of-year 1994 dollars. $t=$ metric ton; IHM = initial heavy metal; $\mathrm{U}=$ uranium. 
TABLE 2 Unit Costs for Management of High-Level Waste ${ }^{a}$

\begin{tabular}{|c|c|c|c|}
\hline Activity & Unit Cost & Operation & $\begin{array}{c}\text { Source } \\
\text { (see Table 8) }\end{array}$ \\
\hline Treatment & $\begin{array}{l}3 \times 10^{6} / \text { canister } \\
1.4 \times 10^{6} / \text { canister } \\
1.5-3.8 \times 10^{6} / \text { canister } \\
548 / \mathrm{ft}^{3}\end{array}$ & $\begin{array}{l}\text { Vitrification ( } 300 \text { canisters total) } \\
\text { Vitrification }(5,282 \text { canisters total) } \\
\text { Vitrification }(14,000-37,000 \\
\text { canisters total) } \\
\text { Vitrification }\end{array}$ & $7,8,9,10,11,12$ \\
\hline Storage & $\begin{array}{l}5.5 / \mathrm{gal}-\mathrm{yr} \\
2.8-4.5 / \mathrm{gal}-\mathrm{yr} \\
0.9 / \mathrm{gal}-\mathrm{yr}\end{array}$ & $\begin{array}{l}\text { Interim tank storage } \\
\left(26 \times 10^{6} \mathrm{gal}\right) \\
\text { Interim tank storage } \\
\quad\left(60.8 \times 10^{6} \text { gal }\right) \\
\text { Interim tank storage } \\
\quad\left(2.75 \times 10^{6} \text { gal }\right)\end{array}$ & $9,10,13,14$ \\
\hline Disposal & $\begin{array}{l}2.07 \times 10^{5} / \text { canister } \\
3.09-3.20 \times 10^{5} / \text { canister }\end{array}$ & $\begin{array}{l}\text { Single repository } \\
\text { Two repositories }\end{array}$ & $9,15,16,17,18$ \\
\hline Transportation & $\begin{array}{l}1.05 \times 10^{4} / \text { canister } \\
13.5 / \text { canister-mi }\end{array}$ & $\begin{array}{l}\text { Truck and rail to first repository } \\
\text { Based on average of }-1,450 \mathrm{mi} \\
\text { one way to first repository }\end{array}$ & 6,16 \\
\hline
\end{tabular}

a Costs are given in beginning-of-year 1994 dollars. A canister of high-level waste (HLW) usually contains between 9,000 and 16,000 gal of equivalent liquid HLW and about 0.5 metric ton of initial heavy metal. 
TABLE 3 Unit Costs for Management of Low-Level Waste ${ }^{a}$

\begin{tabular}{|c|c|c|c|}
\hline Activity & Unit Cost & Operation & $\begin{array}{c}\text { Source } \\
\text { (see Table 8) }\end{array}$ \\
\hline Treatment & $\begin{array}{l}105 / \mathrm{ft}^{3} \\
145 / \mathrm{ft}^{3} \\
282 / \mathrm{ft}^{3} \\
346 / \mathrm{ft}^{3} \\
424 / \mathrm{ft}^{3} \\
568 / \mathrm{ft}^{3}\end{array}$ & $\begin{array}{l}\text { Compaction } \\
\text { Shredding/compaction } \\
\text { Vitrification } \\
\text { Solidification } \\
\text { Incineration } \\
\text { Metal melting }\end{array}$ & $7,19,20,21$ \\
\hline Storage & $160-180 / \mathrm{ft}^{3}-\mathrm{yr}$ & $\begin{array}{l}\text { Interim short-term in } \\
\text { above-grade facility or } \\
\text { shallow land trenches }\end{array}$ & $19,20,21,22,23$ \\
\hline Disposal & $\begin{array}{l}14-171 / \mathrm{ft}^{3} \\
68 / \mathrm{ft}^{3} \\
126 / \mathrm{ft}^{3} \\
190 / \mathrm{ft}^{3} \\
205 / \mathrm{ft}^{3} \\
244-2,182 / \mathrm{ft}^{3}\end{array}$ & $\begin{array}{l}\text { Shallow land trenches } \\
\text { Concrete containment } \\
\text { Above-grade vaults } \\
\text { Below-grade vaults } \\
\text { Concrete canister } \\
\text { Engineered trenches }\end{array}$ & $4,7,20,22,24,25,26$ \\
\hline Transportation & $\begin{array}{l}26 / 55-\mathrm{gal} \text { drum } \\
42 / 85-\mathrm{gal} \text { drum } \\
1.1 / \mathrm{ft}^{3} \\
1.54-1.81 / \mathrm{ft}^{3} \\
2.22-2.38 / \mathrm{ft}^{3} \\
3.0 / \mathrm{ft}^{3} \\
3.65 / \mathrm{ft}^{3}\end{array}$ & $\begin{array}{l}\text { Truck (up to } 500 \mathrm{mi} \text { one way) } \\
\text { Truck (up to } 500 \mathrm{mi} \text { one way) } \\
\text { Up to } 100 \mathrm{mi} \text { one way } \\
100-300 \mathrm{mi} \text { one way } \\
300-500 \mathrm{mi} \text { one way } \\
500-750 \mathrm{mi} \text { one way } \\
750-1,000 \mathrm{mi} \text { one way }\end{array}$ & $4,7,19,20,22$ \\
\hline
\end{tabular}

a Costs are given in beginning-of-year 1994 dollars. 
TABLE 4 Unit Costs for Management of Transuranic Waste ${ }^{a}$

\begin{tabular}{|c|c|c|c|}
\hline Activity & Unit Cost & Operation & $\begin{array}{c}\text { Source } \\
\text { (see Table 8) }\end{array}$ \\
\hline Treatment & $\begin{array}{l}105-158 / \mathrm{ft}^{3} \\
164-257 / \mathrm{ft}^{3} \\
150-527 / \mathrm{ft}^{3} \\
630-1,050 / \mathrm{ft}^{3}\end{array}$ & $\begin{array}{l}\text { Compaction } \\
\text { Solidification } \\
\text { Vitrification } \\
\text { Incineration }\end{array}$ & 7,19 \\
\hline Storage & $\begin{array}{l}\text { 105/ft }{ }^{3} \text {-yr CH-TRU } \\
1,030 / \mathrm{ft}^{3}-\mathrm{yr} \text { RH-TRU }\end{array}$ & $\begin{array}{l}\text { Interim short-term in } \\
\text { shallow land trenches } \\
\text { Interim short-term in } \\
\text { shallow land trenches }\end{array}$ & 19,25 \\
\hline Disposal & $\begin{array}{l}98-402 / \mathrm{ft}^{3} \\
630-780 / \mathrm{ft}^{3}\end{array}$ & $\begin{array}{l}\text { Shallow land trenches } \\
\text { Deep geologic }\end{array}$ & $\begin{array}{l}25,27 \\
7,9,28\end{array}$ \\
\hline Transportation & $\begin{array}{l}42 / \mathrm{ft}^{3} \text { CH-TRU } \\
1,350 / \mathrm{ft}^{3} \mathrm{RH}-\mathrm{TRU} \\
0.012-0.016 / \mathrm{ft}^{3}-\mathrm{mi}\end{array}$ & $\begin{array}{l}\text { Truck (from SRS to WIPP; } \\
2,894 \text { mi per shipment) } \\
\text { Truck (average value) } \\
\text { Based on shipment of } \\
\text { CH-TRU to WIPP }\end{array}$ & $\begin{array}{l}1 \\
19,29 \\
9,30\end{array}$ \\
\hline
\end{tabular}

a Costs are given in beginning-of-year 1994 dollars. $\mathrm{CH}=$ contact-handled; $\mathrm{RH}=$ remote-handled; TRU = transuranic; SRS = Savannah River Site; WIPP = Waste Isolation Pilot Project. 
TABLE 5 Unit Costs for Management of Hazardous Waste ${ }^{a}$

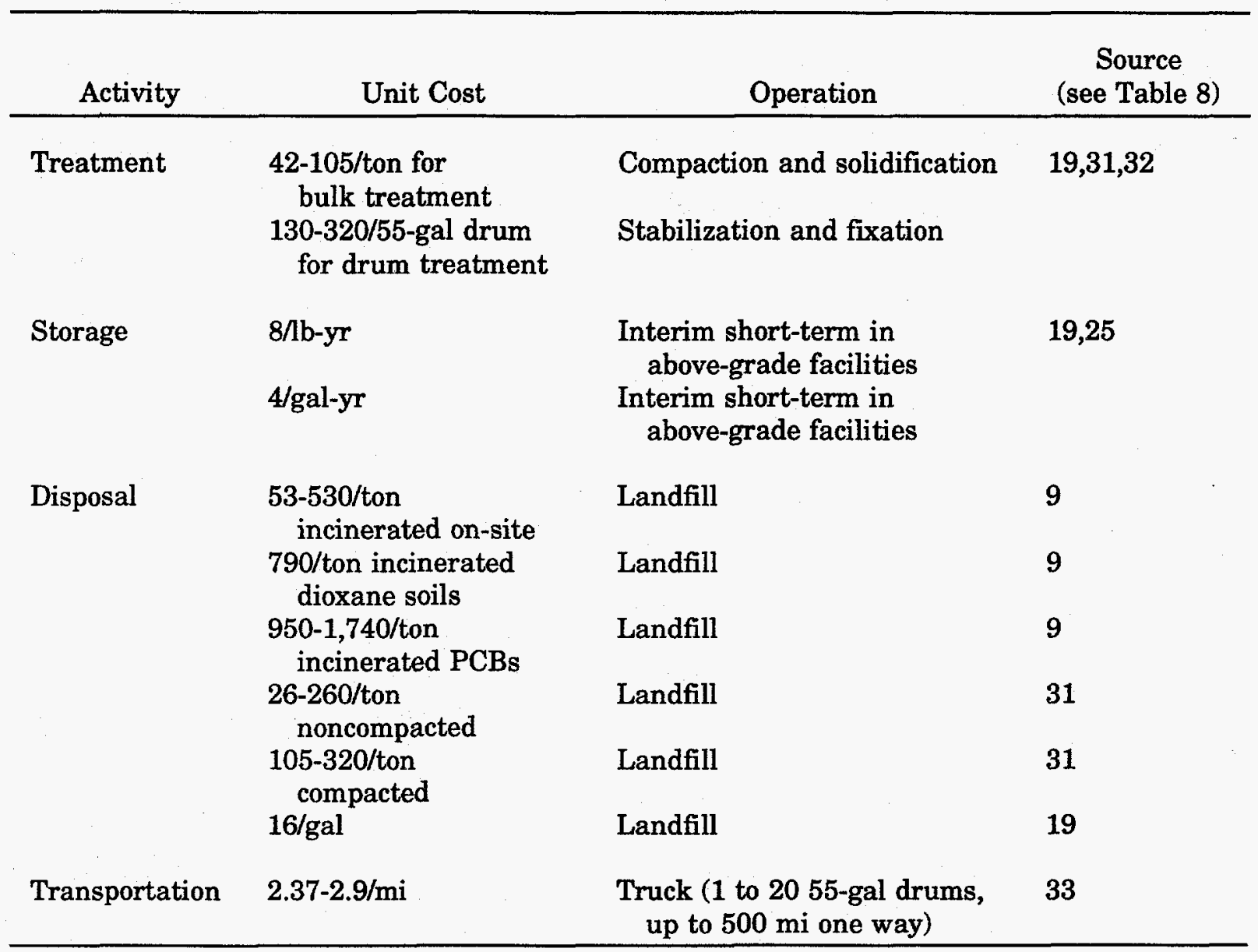

a Costs are given in beginning-of-year 1994 dollars. ton = short ton; PCBs = polychlorinated biphenyls. 
TABLE 6 Unit Costs for Management of Mixed Waste ${ }^{\text {a }}$

\begin{tabular}{|c|c|c|c|}
\hline Activity & Unit Cost & Operation & $\begin{array}{c}\text { Source } \\
\text { (see Table 8) }\end{array}$ \\
\hline \multirow[t]{6}{*}{ Treatment } & $\begin{array}{l}142-676 / \mathrm{ft}^{3} \\
167-1,110 / \mathrm{ft}^{3}\end{array}$ & $\begin{array}{l}\text { Incineration } \\
\text { MW } \\
\alpha \mathrm{MW}\end{array}$ & 7 \\
\hline & $\begin{array}{l}61-1,300 / \mathrm{ft}^{3} \\
214-1,480 / \mathrm{ft}^{3}\end{array}$ & $\begin{array}{l}\text { Metal melting } \\
\text { MW } \\
\alpha \mathrm{MW}\end{array}$ & \\
\hline & $\begin{array}{l}26-153 / \mathrm{ft}^{3} \\
57-508 / \mathrm{ft}^{3}\end{array}$ & $\begin{array}{l}\text { Shredding and compacting } \\
\text { MW } \\
\alpha M W\end{array}$ & \\
\hline & $\begin{array}{l}51-132 / \mathrm{ft}^{3} \\
164-1,310 / \mathrm{ft}^{3}\end{array}$ & $\begin{array}{l}\text { Solidification } \\
\text { MW } \\
\alpha \mathrm{MW}\end{array}$ & \\
\hline & $\begin{array}{l}134-481 / \mathrm{ft}^{3} \\
150-548 / \mathrm{ft}^{3}\end{array}$ & $\begin{array}{l}\text { Vitrification } \\
\text { MW } \\
\alpha \mathrm{MW}\end{array}$ & \\
\hline & 420/gal & $\begin{array}{l}\text { Separation and concentration } \\
\text { (liquids) }\end{array}$ & 19 \\
\hline Storage & $\begin{array}{l}32 / \mathrm{ft}^{3}-\mathrm{yr} \text { (solids) } \\
118 / \text { gal-yr (liquids) }\end{array}$ & $\begin{array}{l}\text { Interim short-term in shallow } \\
\text { land trenches } \\
\text { Interim short-term in shallow } \\
\text { land trenches }\end{array}$ & 25 \\
\hline \multirow[t]{3}{*}{ Disposal } & $231 / \mathrm{ft}^{3}$ & $\begin{array}{l}\text { Shallow land trenches } \\
\text { (compacted) }\end{array}$ & 27 \\
\hline & $290 / \mathrm{ft}^{3}$ & $\begin{array}{l}\text { Shallow land trenches } \\
\text { (incinerated) }\end{array}$ & 9 \\
\hline & $658 / \mathrm{ft}^{3}$ & $\begin{array}{l}\text { Shallow land trenches } \\
\text { (nonincinerated) }\end{array}$ & 9 \\
\hline Transportation & $2.37-2.9 / \mathrm{mi}$ & $\begin{array}{l}\text { Truck ( } 1 \text { to } 2055 \text {-gal drums, } \\
500 \mathrm{mi} \text { one way) }\end{array}$ & 33 \\
\hline
\end{tabular}

a Costs are given in beginning-of-year 1994 dollars. MW $=$ mixed (low-level radioactive plus hazardous) waste; $\alpha \mathrm{MW}=$ alpha-emitting mixed waste. 
TABLE 7 Unit Costs for Management of Sanitary Waste ${ }^{a}$

\begin{tabular}{llll}
\hline \multicolumn{1}{c}{ Activity } & \multicolumn{1}{c}{ Unit Cost } & \multicolumn{1}{c}{ Operation } & \multicolumn{1}{c}{$\begin{array}{c}\text { Source } \\
\text { (see Table 8) }\end{array}$} \\
\hline Treatment & $21-320 /$ ton & $\begin{array}{l}\text { Compaction } \\
\text { (VRF of 2 to 5) }\end{array}$ & 26 \\
Storage & Not applicable & & \\
& & & \\
Disposal & $8.5 / \mathrm{yd}^{3}$ & Landfill (loose) & 34 \\
& $9.6 / \mathrm{yd}^{3}$ & Landfill (compacted) & 34 \\
& $32 / \mathrm{ton}^{3}$ & Landfill (noncompacted) & 9,26 \\
Transportation & $63-105 / \mathrm{h}$ & Truck & 9,26 \\
& $0.45 / \mathrm{ft}^{3}$ & On site at SRS & \\
\hline
\end{tabular}

a Costs are given in beginning-of-year 1994 dollars. VRF = volume reduction factor; ton = short ton; SRS = Savannah River Site. 
TABLE 8 Sources for Tables 1 through $7^{a}$

1. Feizollahi, F., and D. Shropshire, 1993, Waste Management Facilities Cost Information Report for Spent Nuclear Fuel, EGG-WM-10670, EG\&G Idaho, Inc., Idaho Falls, Id., Mar.

2. Tang, Y.S., and J.H. Saling, 1990, "Storage" and "Transportation," in Radioactive Waste Management, pp. 87 and 321-322, Hemisphere Publishing Corp., New York, N.Y.

3. Rod, S.R., 1991, Cost Estimates of Operating On-Site Spent Fuel Pools after Final Reactor Shutdown, PNL-7778, Pacific Northwest Laboratory, Richland, Wash., Aug.

4. U.S. Nuclear Regulatory Commission, 1988, Generic Cost Estimates for the Disposal of Radioactive Wastes, NUREG/CR-4555, rev. 1, Washington, D.C., Sept.

5. McCartney, J.S., and R.B. Cairns, 1984, Cost Comparisons for On-Site Spent Fuel Storage Option, EPRI-NP-3380, Electric Power Research Institute, Palo Alto, Calif.

6. U.S. Department of Energy, 1990a, Analysis of the Total-System Life Cycle Cost for the Civilian Radioactive Waste Management Program, DOE/RW-0295, Office of Civilian Radioactive Waste Management, Washington, D.C.

7. Feizollahi, F., and D. Shropshire, 1992, Waste Management Facilities Cost Information Report, EGG-WTD-10443, p. 166, EG\&G Idaho, Inc., Idaho Falls, Id., Oct. (Value given is based on Waste Isolation Pilot Plant projections.)

8. U.S. Department of Energy, 1987c, Final Environmental Impact Statement - Disposal of Hanford Defense High-Level, Transuranic, and Tank Wastes, DOE/EIS-0113, vol. 2, appendix C, Dec.

9. Street, G.H., et al., 1992, SRS Waste Cost Analysis, WSRC-RP-92-631, Westinghouse Savannah River Company, Aiken, S.C.

10. U.S. Department of Energy, 1991a, Environmental Restoration and Waste Management (EM) Program, Five-Year Plan, Fiscal Years 1993-1997, DOE/S-0089P, Office of Environmental Restoration and Waste Management, Washington, D.C., Aug.

11. U.S. General Accounting Office, 1992a, Independent Technical Review of the Hanford Tank Farm Operations, GAO/RCED-92-99, Washington, D.C., Mar.

12. U.S. General Accounting Office, 1993, Hanford Tank Waste Program Needs Cost, Schedule, and Management Changes, GAO/RCED-93-99, Washington, D.C., Mar.

13. Albuquerque Field Office, 1991, Environmental Restoration and Waste Management FiveYear Plan, Activity Data Sheet 1002-C1, U.S. Department of Energy, Albuquerque, N.M., Sept. 6.

14. U.S. Department of Energy, 1992a, Integrated Data Base for 1992: Spent Fuel and Radioactive Waste Inventories, Projections, and Characteristics, DOE/RW-0006, rev. 8, Office of Civilian Radioactive Waste Management and Office of Environmental Restoration and Waste Management, Washington, D.C. 
TABLE 8 (Cont.)

15. Fountes, C.E., 1991, "Economic Aspects of EPA's HLW Draft Proposed Regulation," Waste Management 9(2):78-81.

16. U.S. Department of Energy, 1990b, Estimates of the Total-System Life Cycle Cost for the Restructured Program: An Addendum to the May 1989 Analysis of the Total-System Life Cycle Cost for the Civilian Radioactive Waste Management Program, DOE/RW-0295P, Office of Civilian Radioactive Waste Management, Washington, D.C.

17. U.S. Department of Energy, 1986a, Perspective on Methods to Calculate a Fee for Disposal of Defense High-Level Waste in Combined (Civilian/Defense) Repositories, DOE/RL-86-10, Washington, D.C.

18. McDonell, W.R., 1986, Economic Analysis of Projected High-Level Waste Immobilization Operations at the Savannah River Plant, DP-MS-86-92, Westinghouse Savannah River Co., Aiken, S.C., Sept. (Projected annual costs total $\$ 91,700,000$, equivalent overall to $\$ 224,000$ per canister for the 410-canister output at 1,682 kilograms per canister.)

19. Argonne National Laboratory, 1993, Institutional Plan FY 1994-FY 1999, fiscal year 1993 budget data, Argonne, Ill., Sept.

20. Harrison, J., 1992, personal communication from Chem Nuclear Systems, Inc., Channahon, Ill., to W. Kisieleski, Argonne National Laboratory, Argonne, Ill.

21. Sivill, T.E., et al., 1993, "Use of Life-Cycle Cost Estimates in the Evaluation of Proposed Waste-Treatment Facilities," in proceedings of the Symposium on Waste Management, Tucson, Ariz., Feb. 28-Mar 4.

22. Geer, G., 1992, personal communication from Commonwealth Edison, Zion Station, Zion, Ill., to W. Kisieleski, Argonne National Laboratory, Argonne, Ill.

23. Donnachie, R., 1991, "The Effects of Land Bar Restrictions: On-Site, Off-Site Economics," Pollution Engineering 23(10):59-65, Oct.

24. Hanrahan, T., 1991, "Economic Analysis of LLRW Disposal Compact Progress," Waste Management 9(2):467-474.

25. U.S. Department of Energy, 1992b, "Oak Ridge Field Office Experience with a Fee-forService System," appendix C in Report on Pricing Options for Waste Management Systems, Charge-Back Financial Working Group, Washington, D.C., June 25.

26. Flower, W., 1992, personal communication from Waste Management Corp., Oak Brook, Ill., to W. Kisieleski, Argonne National Laboratory, Argonne, Ill.

27. Hennig, J.M., 1993, Fiscal Year 1994 Rates for Disposal and Storage of Radioactive Solid Waste at the Hanford Site, memorandum from U.S. Department of Energy, Richland Operations Office, Washington, to distribution, Dec. 8. (The costs are based on 1994 dollars. The planning rates are based on a $5 \%$ escalation per year, a $10-20 \%$ increase in costs due to foreseen decreases in volumes, and a 5\% forecasted increase in costs due to unforeseen regulatory concerns and new requirements.) 
TABLE 8 (Cont.)

28. Frei, M.W., 1992, personal communication from U.S. Department of Energy, Office of Waste Management Projects, Washington, D.C., to J. Schultz, U.S. Government Accounting Office, Washington, D.C., May 13. (Value was developed by assuming $\$ 6.2$ billion life-cycle cost for the Waste Isolation Pilot Plant, total capacity of 6.45 million cubic feet of TRU, 25-year operation, and operating cost of $\$ 156$ million per year.)

29. Jensen, R.T., 1988, "Inventory and Characteristics of Transuranic Waste," Nuclear Chemical Waste Management 4(1):19-24.

30. Los Alamos National Laboratory, 1993, Avoidable Waste Management Costs at DOE Facilities, LA-UR-93-1154, Los Alamos, N.M., Mar. 29.

31. Evans, G.M., 1989, section 14.2 in Standard Handbook of Hazardous Waste Treatment and Disposal: Cost Perspective for Hazardous Waste Management, H.M. Freeman (editor), McGraw-Hill Book Co., New York, N.Y.

32. Pace, R.S., et al., 1992, "Cost Modeling for Environmental Compliance," in proceedings of the Conference on Federal Environmental Restoration, Vienna, Va., Apr. 15-17.

33. Kendrick, R., 1992, personal communication from Bio-Waste Trucking Co., Raleigh, N.C., to W. Kisieleski, Argonne National Laboratory, Argonne, $\mathrm{Il}$.

34. Smith, R., 1992, personal communication from Green Valley Landfill, Downers Grove, Ill., to W. Kisieleski, Argonne National Laboratory, Argonne, Ill.

a These sources are also included in Section 13, which lists all the references cited in this report. If a letter appears after the year of publication in the reference list, it also appears here. 


\section{RADIOACTIVE WASTE}

Many kinds of radioactive wastes are produced by the nuclear industry (Wolfe 1976). There are licensing procedures and regulations to deal with more than 900 radioisotopes (radioactive forms) of 100 elements. Wastes containing these isotopes can (1) be gases, liquids, or solids; (2) be soluble or insoluble; and (3) give off various types of radiation at many energy levels. Although many radioisotopes decay rapidly (in seconds), some require hundreds of years to decay to safe levels.

The hazards of radioactive materials stem from the basic nature of radiation: (1) radiation cannot be detected by the senses; (2) its effects are often cumulative and may not be evident for some time; and (3) it can damage not only the individual who is exposed to it but also, by impairing reproductive cells, future generations of descendants. Fortunately, also because of the basic nature of radiation, its presence can be detected with certainty and remarkable accuracy.

Radioisotopes are immune to outside influence. Each radioisotope decays at its own particular rate regardless of temperature, pressure, or chemical environment and no matter what is done to it. Allowing radioisotopes to decay naturally by putting them in a safe environment is one approach to reducing the hazardous effects of their radioactivity. Recent research and development programs suggest that partitioning and transmutation of actinides and fission products may serve as another approach. However, this approach is not a completely satisfactory alternative to the geological disposal of waste. Transmutation is a time-consuming process and requires reactors with high and/or energetic neutron fluxes. At this stage, the partitioning and transmutation approach needs a very thorough technological and economic analysis.

\subsection{ORIGINS}

In general, radioactive waste is any material that contains or is contaminated with radionuclides at concentrations or radioactivity levels greater than the exempted quantities established by the regulatory body (e.g., the U.S. Nuclear Regulatory Commission) and for which no future use is foreseen. Such waste results from the following activities:

- Uranium mining, milling, and refining. Uranium mill tailings are left behind after the uranium has been removed from the ore. These tailings are considered to be radioactive waste. Almost all of the radium and other uranium decay products become the radioactive constituents of the tailings.

- Nuclear fuel cycle operations such as uranium conversion and enrichment, fuel fabrication, and SNF reprocessing. As of 1994, 11 countries have operated demonstration or industrial-scale enrichment facilities, 19 have fabricated uranium oxide $\left(\mathrm{UO}_{2}\right)$ and/or plutonium 
oxide $\left(\mathrm{PuO}_{2}\right)$ fuels, and 15 are or are planning to reprocess SNF. Since 1977, the U.S. Government has deferred reprocessing commercial SNF; however, some defense-related SNF has been reprocessed as part of the national defense program.

- Operations of nuclear facilities. At the end of 1994, 430 nuclear power reactors with a total capacity of 387,718 megawatts-electric were operating in 29 countries. Radioactive waste also results from the operations of facilities used to produce nuclear weapons.

- Decontamination and decommissioning of nuclear facilities. By the year 2000 , about 64 nuclear power plants and 256 nuclear research reactors throughout the world will be reaching 30 years of age. Other facilities being decontaminated and decommissioned include fuel fabrication facilities, hot cells, and research laboratories.

- Institutional uses of isotopes. These activities are widespread and involve the use of radionuclides and radiation sources in medicine, research (including research reactors and test facilities), industry, and agriculture.

\subsection{SOURCES AND INVENTORIES}

All civilian and military activities involving radioactive materials produce radioactive wastes. Examples are nuclear-fuel-related activities; reactor operations; nuclear weapons production; scientific research that uses radioisotopes; medical operations that use radioisotopes for research, diagnosis, and therapy; and production of radiopharmaceuticals.

To provide a perspective of the volume of wastes involved, Tables 9 and 10 present data on the total inventory of radioactive wastes through 1991. Table 9 presents data on the total volume of commercial and DOE/defense-related wastes and SNF through 1991, and Table 10 presents data on their total radioactivity.

Data on the projected inventory of radioactive wastes through 2000 is shown in Tables 11 and 12. Table 11 presents data on the projected volume of commercial and DOE wastes and SNF through 2000 , and Table 12 presents data on their projected radioactivity.

Spent nuclear fuel is generated by 110 reactors at nearly 70 commercial nuclear stations in 33 states. The existing SNF inventory comes to roughly 27,000 metric tons (t); by 2010 , this figure will probably increase to nearly $59,000 \mathrm{t}$. SNF is also generated in various nuclear reactors operated for research and national defense purposes. This inventory amounts to about $2,300 \mathrm{t}$ of uranium. 
TABLE 9 Total Volume of Commercial and DOE Wastes and Spent Nuclear Fuel through $1991^{\mathrm{a}}$

\begin{tabular}{|c|c|c|c|}
\hline $\begin{array}{l}\text { Waste } \\
\text { Type }\end{array}$ & Source & $\begin{array}{l}\text { Volume } \\
\left(\mathrm{m}^{3}\right)\end{array}$ & Percent \\
\hline HLW & $\begin{array}{l}\text { Commercial } \\
\text { DOE } \\
\text { Total }\end{array}$ & $\begin{array}{l}1.729 \times 10^{3} \\
3.949 \times 10^{5} \\
3.966 \times 10^{5}\end{array}$ & $\begin{array}{l}0.03 \\
8.1\end{array}$ \\
\hline LLW & $\begin{array}{l}\text { Commercial } \\
\text { DOE } \\
\text { Total }\end{array}$ & $\begin{array}{l}1.423 \times 10^{6} \\
2.816 \times 10^{6} \\
4.239 \times 10^{6}\end{array}$ & $\begin{array}{l}29.0 \\
57.5\end{array}$ \\
\hline TRU & & $2.554 \times 10^{5}$ & 5.2 \\
\hline SNF & & $9.546 \times 10^{3}$ & 0.19 \\
\hline Total & & $4.900 \times 10^{6}$ & \\
\hline
\end{tabular}

a $\mathrm{HLW}=$ high-level waste; LLW = low-level waste; TRU = transuranic; SNF = spent nuclear fuel.

Source: DOE (1992a).

TABLE 10 Total Radioactivity of Commercial and DOE Wastes and Spent Nuclear Fuel through $1991^{\mathrm{a}}$

\begin{tabular}{|c|c|c|c|}
\hline $\begin{array}{l}\text { Waste } \\
\text { Type }\end{array}$ & Source & $\begin{array}{l}\text { Radioactivity } \\
\text { (Ci) }\end{array}$ & Percent \\
\hline HLW & $\begin{array}{l}\text { Commercial } \\
\text { DOE } \\
\text { Total }\end{array}$ & $\begin{array}{l}2.621 \times 10^{7} \\
9.707 \times 10^{8} \\
9.969 \times 10^{8}\end{array}$ & $\begin{array}{l}0.1 \\
4.01\end{array}$ \\
\hline LLW & $\begin{array}{l}\text { Commercial } \\
\text { DOE } \\
\text { Total }\end{array}$ & $\begin{array}{l}5.651 \times 10^{6} \\
1.343 \times 10^{7} \\
1.908 \times 10^{7}\end{array}$ & $\begin{array}{l}0.02 \\
0.06\end{array}$ \\
\hline TRU & & $2.772 \times 10^{6}$ & 0.01 \\
\hline SNF & & $2.325 \times 10^{10}$ & 95.8 \\
\hline Total & & $2.426 \times 10^{10}$ & \\
\hline
\end{tabular}

a $H L W=$ high-level waste; LLW = low-level waste; TRU = transuranic; SNF = spent nuclear fuel.

Source: DOE (1992a). 
TABLE 11 Projected Volume of Commercial and DOE Wastes and Spent Nuclear Fuel through $2000^{\mathrm{a}}$

\begin{tabular}{llll}
\hline $\begin{array}{c}\text { Waste } \\
\text { Type }\end{array}$ & \multicolumn{1}{c}{ Source } & \multicolumn{1}{c}{$\begin{array}{c}\text { Volume } \\
\left(\mathrm{m}^{3}\right)\end{array}$} & Percent \\
\hline HLW & Commercial & 240 & 0.003 \\
& DOE & $3.336 \times 10^{5}$ & 4.4 \\
& Total & $3.338 \times 10^{5}$ & \\
LLW & Commercial & $1.722 \times 10^{6}$ & 22.6 \\
& DOE & $4.707 \times 10^{6}$ & 61.7 \\
& Total & $6.429 \times 10^{6}$ & \\
TRU & & $8.450 \times 10^{5}$ & 11.1 \\
SNF & & & \\
\hline
\end{tabular}

a $\mathrm{HLW}=$ high-level waste; LLW = low-level waste; TRU = transuranic; SNF = spent nuclear fuel.

Source: DOE (1992a).

TABLE 12 Projected Radioactivity of Commercial and DOE Wastes and Spent Nuclear Fuel through $\mathbf{2 0 0 0}^{\mathrm{a}}$

\begin{tabular}{|c|c|c|c|}
\hline $\begin{array}{l}\text { Waste } \\
\text { Type }\end{array}$ & Source & $\begin{array}{l}\text { Radioactivity } \\
\text { (Ci) }\end{array}$ & Percent \\
\hline HLW & $\begin{array}{l}\text { Commercial } \\
\text { DOE } \\
\text { Total }\end{array}$ & $\begin{array}{l}2.12 \times 10^{7} \\
9.93 \times 10^{8} \\
1.014 \times 10^{9}\end{array}$ & $\begin{array}{l}0.06 \\
2.9\end{array}$ \\
\hline LLW & $\begin{array}{l}\text { Commercial } \\
\text { DOE } \\
\text { Total }\end{array}$ & $\begin{array}{l}5.403 \times 10^{6} \\
1.188 \times 10^{7} \\
1.728 \times 10^{7}\end{array}$ & $\begin{array}{l}0.02 \\
0.03\end{array}$ \\
\hline TRU & & $2.284 \times 10^{6}$ & 0.007 \\
\hline SNF & & $3.330 \times 10^{10}$ & 97 \\
\hline
\end{tabular}

a HLW = high-level waste; LLW = low-level waste; TRU = transuranic; SNF = spent nuclear fuel.

Source: DOE (1992a). 


\section{SPENT NUCLEAR FUEL}

Spent nuclear fuel (SNF) is fuel that has been discharged from a reactor. The reactor can be a commercial power reactor, weapons production reactor, or research reactor. Once removed, the SNF is usually placed into temporary on-site storage. Then one of two things happens.

- The SNF is placed in interim storage (5 to 100 years), conditioned (nonfuel-bearing components are removed to reduce the volume of waste to be stored) after a sufficient decay period, and stored until its final disposition in a geologic repository.

- The SNF is placed in interim storage and then reprocessed. In reprocessing, the resulting liquid HLW, containing mostly fission products and a small proportion of the actinides, is immobilized in a stable matrix (e.g., borosilicate glass). The next step is for the HLW to be disposed of in a geologic repository (see Section 6). However, in 1977, the U.S. government deferred commercial reprocessing indefinitely. Reprocessing for national defense purposes continued for several more years. In 1981, the U.S. government rescinded its decision to not allow reprocessing of commercial SNF. Market forces have not provided sufficient impetus for the development of this industry. As a result, the SNF inventories continue to grow at commercial nuclear power plants.

There is broad scientific agreement that deep geologic disposal that uses a system of engineered and natural barriers to isolate these wastes is the preferred method for their disposal.

Typically, SNF is measured in terms of either the number of discharged fuel assemblies or the quantity of discharged fuel mass. The quantity is measured either in metric tons of heavy metal ( $\mathrm{t} \mathrm{HM}$ ), in which only the heavy metal (i.e., uranium, thorium, plutonium) content of the SNF is considered, or in metric tons of initial heavy metal ( $\mathrm{IHM}$ ), which reflects the initial mass of the fuel before irradiation. In some cases, metric tons of uranium $(\mathrm{t} \mathrm{U}$ ) or kilograms of uranium $(\mathrm{kg} \mathrm{U})$ are used as the units of measure.

The total inventory of SNF from commercial light water reactors (LWRs) in storage as of December 1, 1991, amounted to 23,681 t IHM. The amount of DOE SNF no longer scheduled for reprocessing as of December 1, 1991, totalled 2,155 t IHM, of which 2,128 $t$ IHM was located at the Hanford Site in Washington (DOE 1992a).

Commercial nuclear power plants were typically designed with the capability to store a full core of the SNF on-site in water pools (wet storage) for approximately 5 years. The U.S. utilities have realized that without a reprocessing industry that includes both an interim storage program and a monitored retrievable storage facility, on-site water pool storage sites will eventually lack the capacity to accommodate the increasing inventories of SNF 
(DOE 1984). Efforts to expand on-site storage capabilities and to develop alternative storage systems were thus initiated.

\subsection{TREATMENT}

Spent nuclear fuel contains not only radioactive fission products that require disposal in a deep geologic repository but also potentially useful plutonium, reusable irradiated uranium, and other elements such as precious metals in the platinum group. There are two primary alternatives for treating SNF:

1. In the direct disposal approach, SNF is directly disposed of, after appropriate treatment. Fissile components have not been separated from the fuel.

2. In the reprocessing approach, SNF is reprocessed to recover plutonium and uranium for reuse as nuclear fuel, and the resultant HLW, containing mostly fission products and a small proportion of the actinides, is disposed of after proper treatment.

The choice between these two approaches depends on a number of factors, including political and economic considerations, social effects, regulations, technical feasibility, and the availability of resources. Currently, SNF is not reprocessed in the United States. Thus, the only SNF treatment option considered in this report is its packaging in a container suitable for long-term interim storage and/or final disposal.

A typical reference container used to dispose of SNF in a geologic repository is a thinwalled circular cylinder (canister) with an end closure and a lifting fixture on one end. The canister's outer diameter is 660 millimeters $(\mathrm{mm})$ and its length is $4,762 \mathrm{~mm}$, and it has a nominal wall thickness of $10 \mathrm{~mm}$. The canister has an internal configuration that holds up to four intact PWR assemblies or 10 intact BWR assemblies or a combination of three PWR and four BWR assemblies.

The primary purpose of the treatment facility is to prepare SNF for direct disposal in a federal repository. Here in the treatment facility, loaded transport casks are received; the SNF from these casks is unloaded; and the physical, chemical, and radiological properties of the SNF are characterized. The characterized SNF is then placed in repository canisters that are sealed for long-term storage and disposal. If necessary, containers that are degraded because of corrosion, damage, or other reasons are replaced. Because dry handling techniques are used in this facility, the SNF to be processed is limited to fuel that has aged longer than 5 years (due to shielding and criticality concerns) and has low decay heat levels. Newly generated SNF would be characterized and packaged under water in a wet pool for shielding and criticality purposes. 
Many factors can affect the unit cost of SNF treatment. These factors include:

- Mode of packaging (wet versus dry; in this analysis, dry packaging is assumed);

- Treatment capacity; and

- Duration of operations.

For a given duration (assumed to be 20 years for the data reported herein), the primary factor that determines the capital and annual operating costs is treatment capacity (throughput). A summary of unit costs for SNF treatment is given in Table 13 and Figure 1 as a function of treatment capacity (Feizollahi and Shropshire 1993; Sire et al. 1992; DOE 1990b).

As shown by these data, SNF treatment that use dry techniques is costly, primarily because (1) remote handling capabilities are required for all ongoing characterization and packaging activities (all major activities are performed within hot cells); (2) a high degree of shielding of beta-gamma radiation sources is required so that the radiation exposure to humans is as low as reasonably achievable; (3) alpha contamination must be controlled; and (4) the capability to process the wide variety and types of fuel compositions, sizes, and claddings must be ensured. The majority of the SNF could be packaged wet (underwater) by using simple, relatively inexpensive equipment, but this method of packaging would only provide short-term containment, and the resulting package would not meet the waste acceptance criteria for repository disposal without removal of the water and subsequent drying of the container contents.

Of major concern is the characterization of SNF for ultimate disposal. There are about 90 different types of SNF in current inventories. It will require considerable effort to characterize many of these fuels for final disposal. These fuels include graphite and carbides, uranium and aluminum alloys, thorium, zirconium cermets, and miscellaneous fuels used for research and development. Before they are disposed of directly in a repository, these fuels will require successful characterization to fulfill U.S. Nuclear Regulatory Commission (NRC) licensing requirements.

TABLE 13 Unit Costs for Treatment of Spent Nuclear Fuel as a Function of Treatment Capacity ${ }^{a}$

\begin{tabular}{|c|c|}
\hline $\begin{array}{l}\text { Throughput } \\
\text { (t U-yr) }\end{array}$ & $\begin{array}{l}\text { 20-yx Unit Cost } \\
(\$ / \mathrm{kg} \mathrm{U})\end{array}$ \\
\hline 5 & 5,110 \\
\hline 50 & 1,140 \\
\hline 144 & $980^{b}$ \\
\hline 3,000 & 18 \\
\hline \multicolumn{2}{|c|}{$\begin{array}{l}\text { Costs are given in beginning-of- } \\
\text { year } 1994 \text { dollars. } t=\text { metric ton; } \\
U=\text { uranium. }\end{array}$} \\
\hline \multicolumn{2}{|c|}{$\begin{array}{l}\text { bost estimate in Sire et al. (1992) } \\
\text { did not include decontamination } \\
\text { and decommissioning cost; it was } \\
\text { assumed for this analysis to be } \\
12 \% \text { of the capital cost. }\end{array}$} \\
\hline
\end{tabular}

Sources: Feizollahi and Shropshire (1993); Sire et al. (1992); DOE (1990b). 


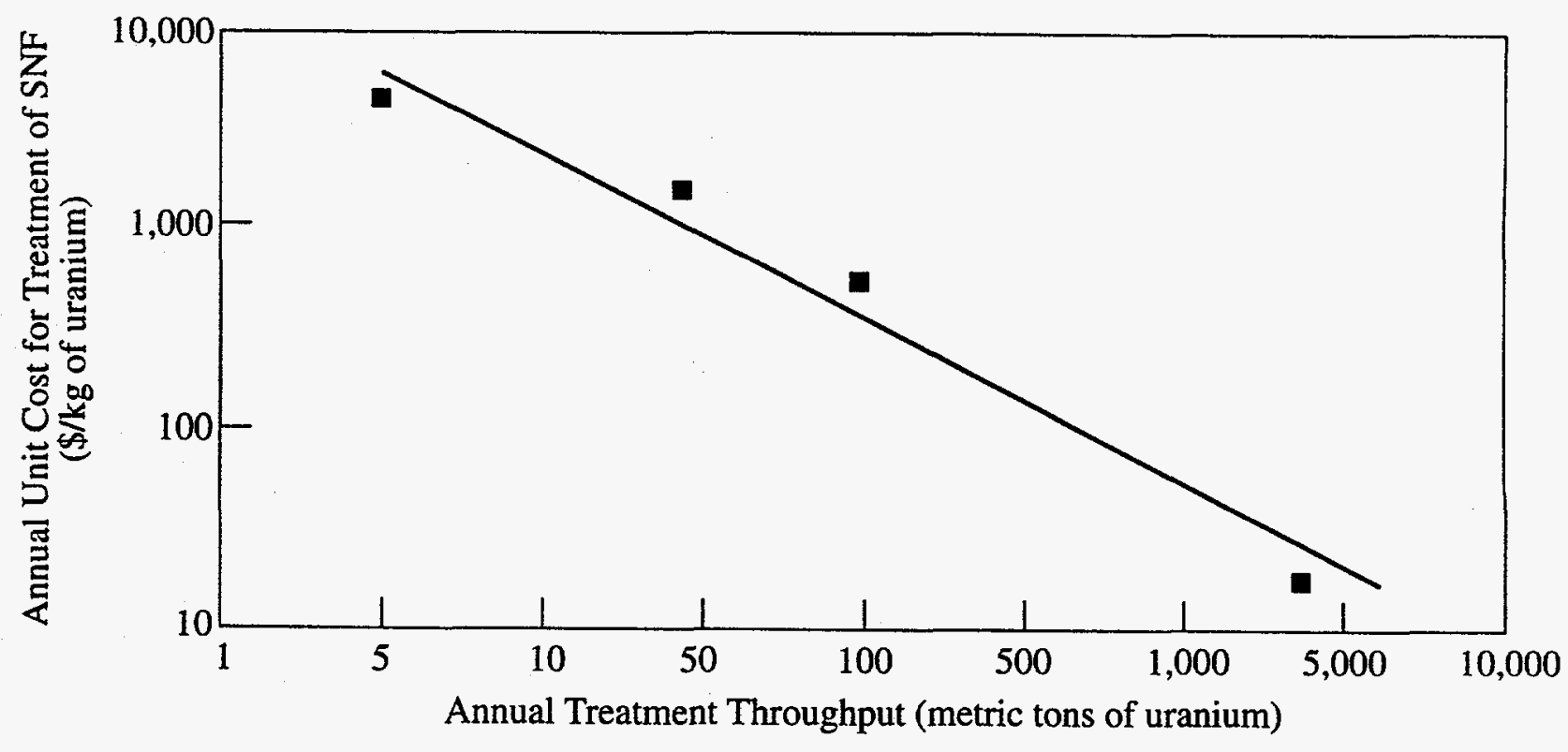

FIGURE 1 Unit Costs for Treatment of Spent Nuclear Fuel

\subsection{STORAGE}

The basic scheme underlying the plans for increasing storage capacity is to provide for interim storage of SNF for a limited period, then send it to a reprocessing plant or for final disposal. The choice of a specific technology for increasing storage capacity depends not only on the individual cost components of the technology but also on other factors that can have a direct effect on the unit cost of storage. The individual components of the unit storage cost can be broken down into the following categories:

- Initial investment cost (capital cost), which includes the costs of design, development, and construction;

- Operating cost during the time when the fuel is stored, which includes the costs of labor, consumable products, maintenance, and secondary waste management; and

- Decommissioning cost at the end of the lifetime of the storage facility.

Other factors that can have a direct effect on the unit cost of storage include the following (International Atomic Energy Agency 1991; Tang and Saling 1986):

- SNF characteristics,

- Storage site, 
- Storage capacity, and

- Storage life.

For a given storage technology, the most important factor in determining capital investment and operating costs is storage capacity ( $\mathrm{HM}$ ). This is also the most important factor in determining decommissioning costs, which are usually taken to be a percentage of the capital investment cost.

Unit storage costs $(\$ / \mathrm{kg} \mathrm{U}-\mathrm{yr})$ for options available to meet added storage requirements are shown as a function of storage capacity $(\mathrm{t} \mathrm{U}$ ) in Table 14 (Klepfer and Bowser 1991; DOE 1989a; Feizollahi and Shropshire 1993; Johnson 1990). Costs are presented for reracking, rod consolidation, water basin (wet pool) storage, modular vaults, horizontal concrete modules, and metal storage casks. Costs for water basin storage, modular vaults, horizontal concrete modules, and metal storage casks are determined on the basis of the assumption that new facilities will have to be built; costs for reracking and rod consolidation are determined on the basis of the assumption that existing facilities will be modified. Data for each of the related options are shown graphically in Figures 2-4.

\subsubsection{Wet Storage Options}

\subsubsection{Reracking}

Reracking of existing wet storage pools is intended to achieve more closely packed storage of SNF assemblies. In general, the storage racks originally used in wet pools have a large center-to-center spacing between fuel assemblies. The spacing can be modified by replacing existing racks with higher density storage racks that do not contain a neutron poison for criticality assurance or with very high density storage racks that contain a neutron poison. As shown in Table 14, depending on the amount of additional storage capacity gained, reracking can result in the lowest cost and thus may be the most desirable method for increasing storage capacity when large capacity increases are desired. Reracking costs are usually greater for BWR fuel than PWR fuel because of the somewhat lower consolidation rates and larger number of fuel assemblies (per unit mass of IHM) that are handled.

\subsubsection{Rod Consolidation}

Rod consolidation provides more effective use of existing space in an existing SNF storage pool (Zacha 1988). Rod consolidation involves (1) removing the end fitting(s) from an assembly, (2) pulling and or pushing the fuel rods from the assembly structure, (3) placing the loose fuel rods into a more closely packed array, and (4) compacting the disassembly hardware and placing the result into a canister for interim storage. The net gain in storage capacity for water basin interim storage is about 1.5 to 1.7 times that of the original rack capacity; thus, in general, the equivalent of 2.5 to 2.7 fuel assemblies can be stored in the 
TABLE 14 Unit Costs for Storage of Spent Nuclear Fuel as a Function of Storage Technology and Capacity ${ }^{\mathrm{a}}$

Annual Unit Storage Cost ( $\$ / \mathrm{kg}$ of uranium)

\begin{tabular}{|c|c|c|c|c|c|c|}
\hline $\begin{array}{l}\text { Capacity } \\
\text { (t U) }\end{array}$ & Reracking & $\begin{array}{c}\text { Rod } \\
\text { Consolidation }\end{array}$ & $\begin{array}{c}\text { Water } \\
\text { Basin } \\
\text { (Wet Pool) }\end{array}$ & $\begin{array}{l}\text { Modular } \\
\text { Vaults }\end{array}$ & $\begin{array}{c}\text { Horizontal } \\
\text { Concrete } \\
\text { Modules }\end{array}$ & $\begin{array}{c}\text { Metal } \\
\text { Storage } \\
\text { Casks }\end{array}$ \\
\hline 500.0 & $1-2$ & $1-3$ & $11-21$ & $5-8$ & $1-2$ & $4-5$ \\
\hline 276.0 & 3 & 2 & 26 & 19 & 6 & 8 \\
\hline 230.0 & -- & -- & -- & $13-17$ & $10-13$ & $11-15$ \\
\hline 140.0 & -- & -- & -- & 72 & -- & - \\
\hline 92.0 & 21 & 11 & 150 & 94 & 22 & 27 \\
\hline 90.0 & - & -- & -- & - & 46 & -- \\
\hline 56.0 & -- & -- & 390 & - & -- & -- \\
\hline 17.2 & -- & - & -- & 1,810 & - & -- \\
\hline 5.6 & - & -- & 2,690 & - & -- & - \\
\hline
\end{tabular}

a Costs are in beginning-of-year 1994 dollars. $t=$ metric ton; $\mathrm{U}=$ uranium.

Sources: Klepfer and Bowser (1991); DOE (1989a); Feizollahi and Shropshire (1993); Johnson (1990).

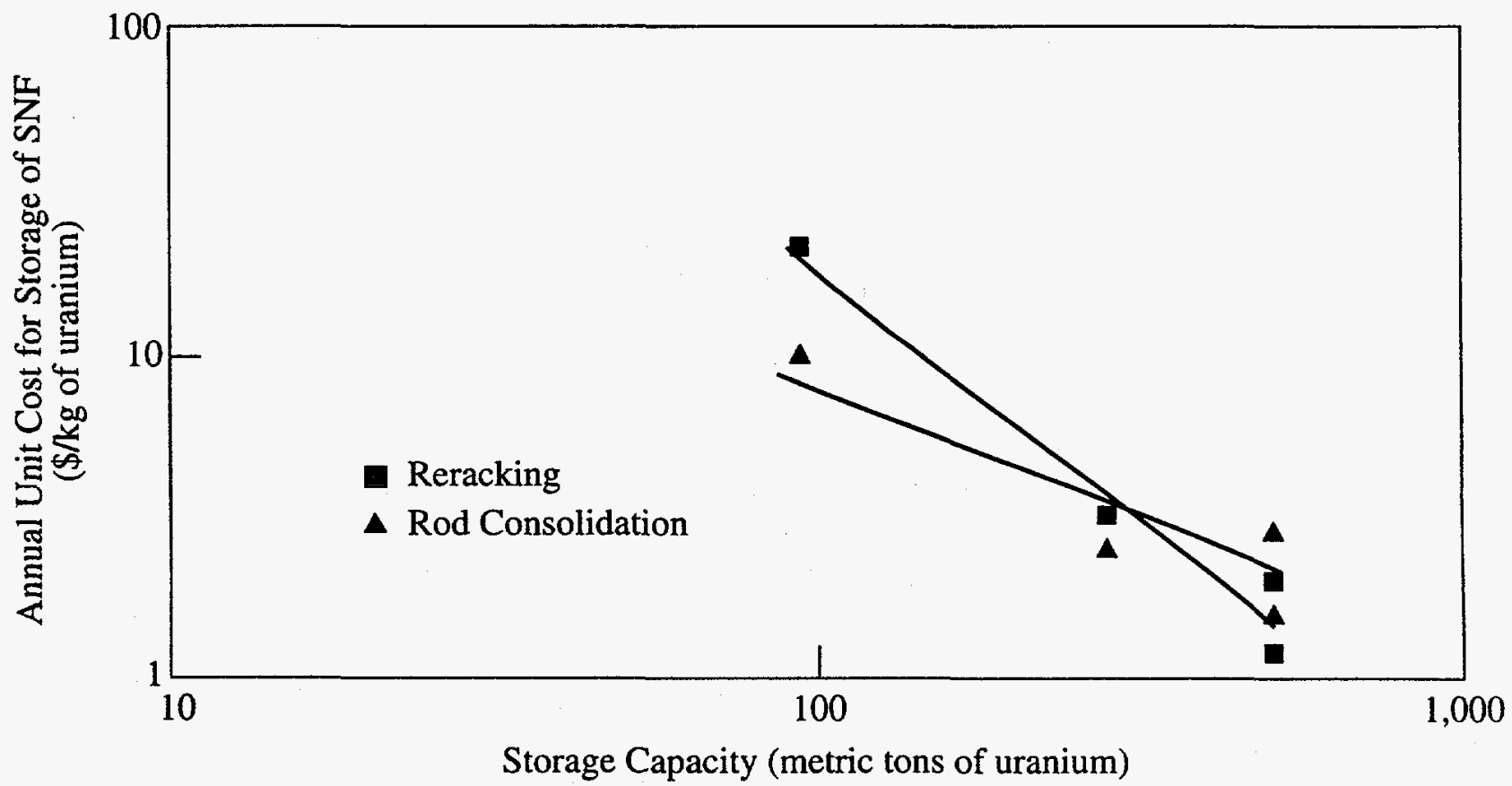

FIGURE 2 Unit Costs for Storage of Spent Nuclear Fuel in Wet Storage Pools: Reracking and Rod Consolidation 


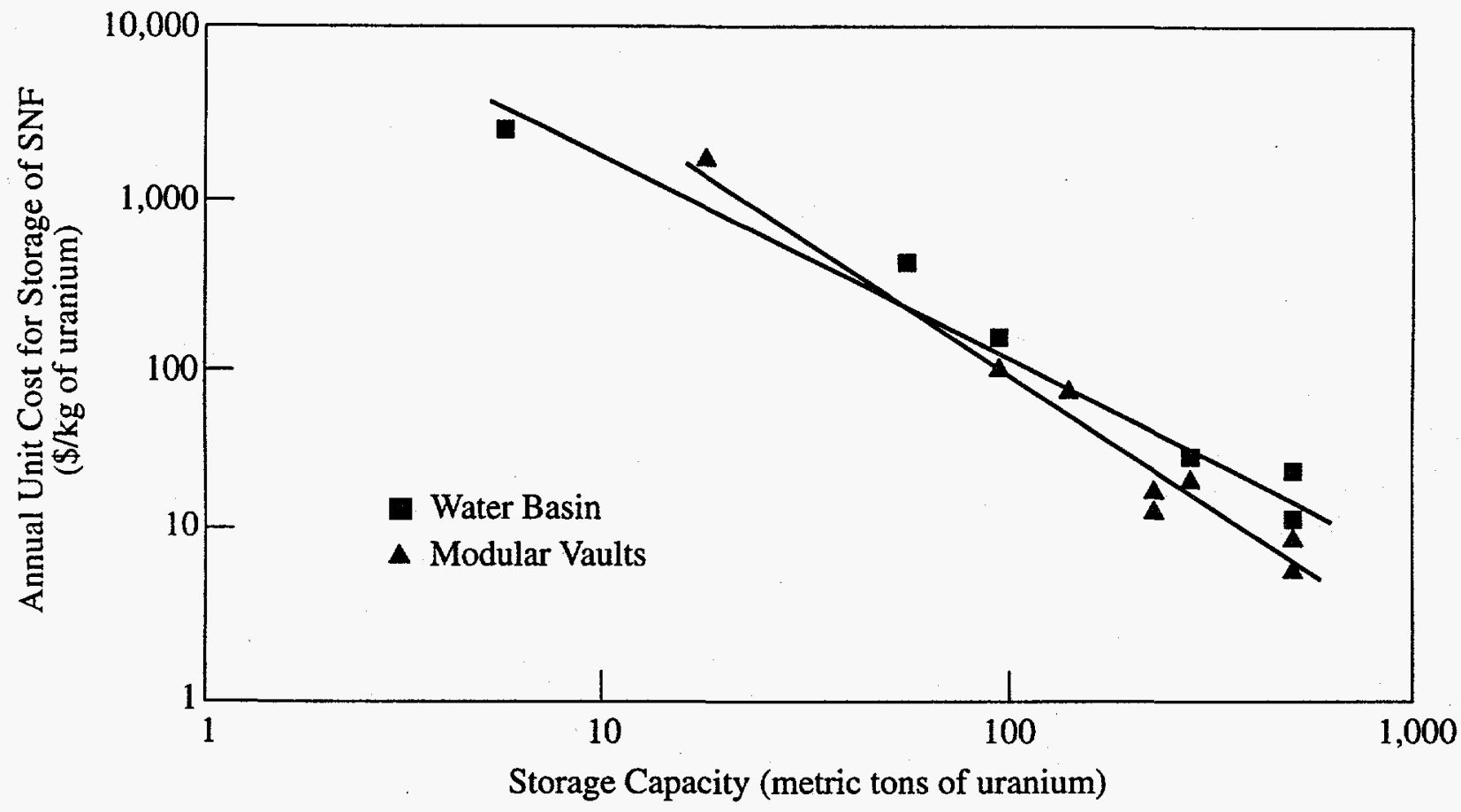

FIGURE 3 Unit Costs for Storage of Spent Nuclear Fuel in Water Basins and Modular Vaults

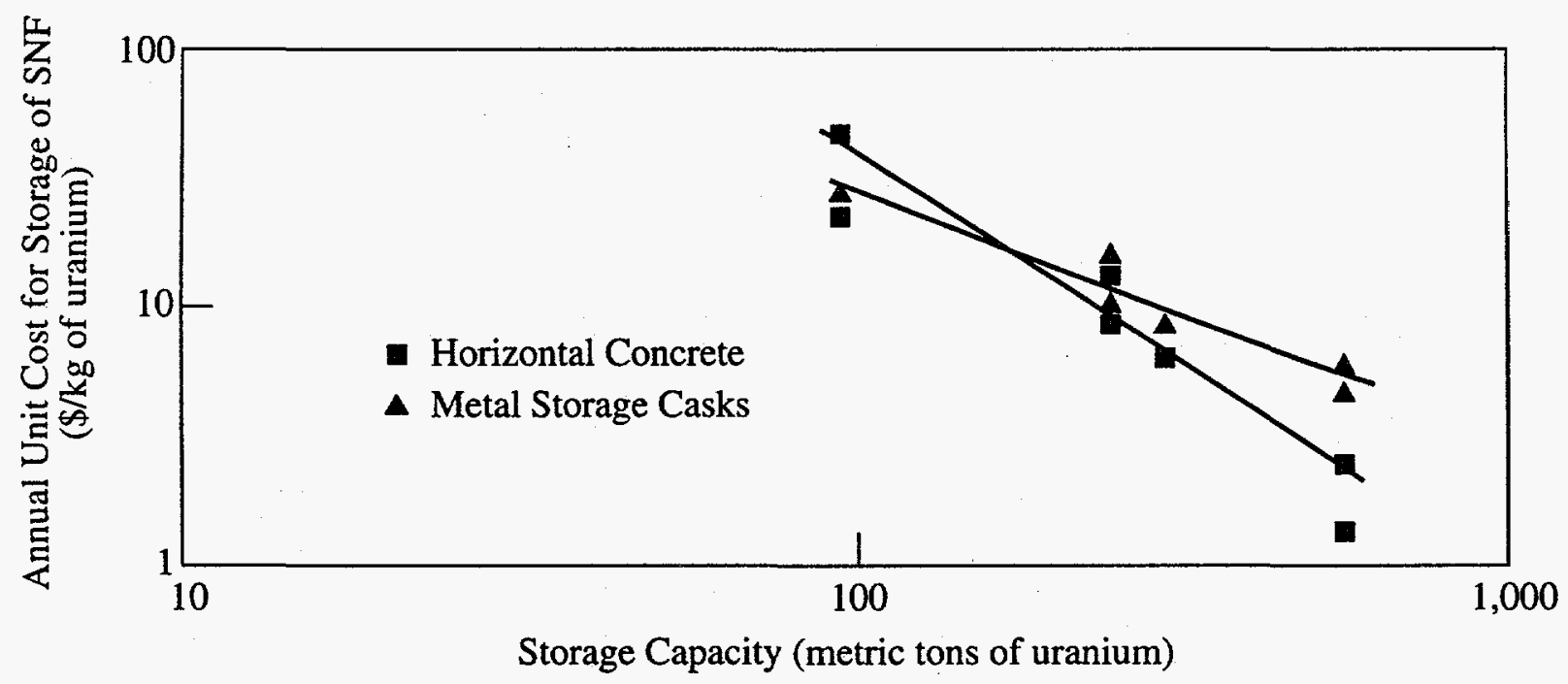

FIGURE 4 Unit Costs for Storage of Spent Nuclear Fuel in Horizontal Concrete Vaults and Metal Storage Casks 
same space previously occupied by only one unconsolidated fuel assembly. Rod consolidation technology is in the advanced demonstration stages. Its estimated unit cost ranges from $\$ 1$ to $\$ 11 / \mathrm{kg} \mathrm{U}$-yr over a range of capacities (from 90 to $500 \mathrm{t} \mathrm{U}$ ). Rod consolidation could be the least-cost approach when small capacity increases (of about $100 \mathrm{t} U$ ) are desired.

\subsubsection{Water Basins}

Storage of SNF in water basins (wet pool storage) is a well-established technology. Such storage facilities have been licensed by the NRC and its predecessor agency for more than 30 years. Major disadvantages are that this storage option requires a long construction period and high initial capital investment before the start of storage operations. Because water basins are not modular, total storage capacity may not be used for many years. In addition, the continued operation of a water basin requires water to be pumped at high flow rates (for cooling) through a heat exchanger (where heat is transferred to chilled water from a cooling tower or its equivalent) and basin water to be purified by external ion-exchange columns to remove dissolved and suspended radionuclides. The lack of modularity coupled with higher operating expenses because of the increased day-to-day attention results in higher unit costs than those of modular technologies such as metal storage casks or horizontal storage modules. However, water basin storage will continue to be used to store SNF immediately after it is discharged from the reactor because wet pool storage efficiently and effectively removes heat and shields personnel from radiation.

\subsubsection{Dry Storage Options}

In addition to the wet storage options, storage capacity can be increased by providing dry storage in various types of casks, modules, or vaults located outside the wet pools (Godlewski 1987; Richards and Szulinski 1979). Dry storage technologies include modular vaults, prefabricated horizontal concrete modules, and transportable metal storage casks (Rasmussen 1988; Garner 1989).

\subsubsection{Transportable Metal Casks}

In the United States, the storage of SNF in metal casks is the most mature of all technologies available for interim dry storage (DOE 1989a). Storage of SNF in metal storage casks has been demonstrated since 1984. The unit cost of storage in metal casks depends not only on the size (capacity) of the storage installation but also on the prevalence of usage of this technology. A metal storage cask is a movable, reinforced, metal radiation shield stored above the ground. The decay heat from the SNF is dissipated by conduction through the cask structure into the atmosphere (i.e., no air flows through the metal cask). The procedure for placing SNF into metal casks involves loading the SNF from a water basin into a waiting cask that has been placed in the basin. When the cask is filled with SNF, the inner shielding lid is secured and the cask is withdrawn from the basin. The cask is drained of pool water and dried by air, after which the outer lid is welded in place. Loaded casks are placed either 
vertically or horizontally on concrete pads for long-term interim storage. Metal casks generally have a capacity for storing 21 to 32 PWR assemblies or 52 to 76 BWR assemblies. The major cost components are the storage casks (about $90 \%$ of the unit cost) and the cask transporter and storage area (about 6\% of the unit cost). Metal casks (as well as concrete storage modules) are attractive because storage capacity can be expanded quickly and in small increments.

\subsubsection{Concrete Modules}

There are three concrete storage modules commercially available in the United States:

- Nutech horizontal storage module (NUHOMS),

- NUPAC vertical storage cask, and

- B\&W CONSTAR vertical storage cask.

The discussion in this paragraph arbitrarily focuses on the NUHOMS concept. The loading procedure for concrete storage modules is similar to that for metal casks, except a metal canister replaces the metal cask. This canister is removed from the basin, dried, inserted into a concrete module, and stored in a horizontal position. The decay heat from the SNF is removed by radiation, conduction, and natural convection through air channels in the concrete storage module. The number of storage modules is increased to meet additional storage requirements. The capacity of a single NUHOMS canister can range from 1 to 24 PWR assemblies or from 2 to 52 BWR assemblies. The major cost components are the transfer cask, transporter, and auxiliary equipment (about 15\%) and the canister/horizontal storage modules (about $80 \%$ ). The unit costs for the NUHOMS system are very competitive with those of the other storage options. Costs for vertically loaded concrete casks such as NUPAC and CONSTAR would be similar to those for NUHOMS. Production-level demonstrations of the NUHOMS technology are currently underway.

\subsubsection{Modular Vaults}

The modular vault storage concept is another dry storage technology that is just beginning to be used in this country; it is a well-established technology in the United Kingdom. This concept involves packaging SNF into stainless-steel (or another similar metal) canisters and storing them in heavily shielded, partially buried concrete vaults. Increases in storage capacity are achieved by increasing the number of concrete vaults. Cooling is provided by natural convection of air passing once through the SNF canisters. The passive cooling system does not require forced convection, as wet pool storage does. In the past, the principal disadvantages of modular vaults have been similar to those of wet pool storage: high initial capital cost and inflexibility with respect to changing storage requirements. Current designs allow for modular construction, resulting in lower unit costs for storage. In 
addition, natural convection vaults are reported to require a minimal amount of operational and maintenance attention, resulting in lower annual operating costs than those of wet pool storage.

\subsection{DISPOSAL}

Under the provisions of the Nuclear Waste Policy Act of 1982 (NWPA) (U.S. Congress 1983), DOE is charged with siting, designing, building, and operating a geologic repository for the long-term internment of SNF and HLW. The Nuclear Waste Policy Amendments Act of 1987 limits the capacity of the first geologic repository to a total of 70,000 $\mathrm{t} \mathrm{HM}$, including $640 \mathrm{t} \mathrm{HM}$ of civilian $\mathrm{HLW}$ and 17,750 canisters of defense-related $\mathrm{HLW}$.

The only disposal option being considered is that the SNF, either consolidated or unconsolidated but without being reprocessed, be disposed of in a geologic repository. Yucca Mountain, Nevada, is currently being characterized to serve in this capacity (DOE 1985). The advantages of deep disposal at Yucca Mountain, which is within the Nevada Test Site, include the site's geology, dry climate, and geographical location in a remote area of a sparsely populated desert region. The underground repository would be constructed about 1,000 feet below the eastern flank of Yucca Mountain and above the water table (which lies as much as 2,500 feet below the land surface). The primary medium for the underground repository is in the welded tuff (ash falls). The tuff is stated to be stable, with a high resistance to creep, a condition that allows the use of thin-walled, corrosion-resistant containers (canisters) for SNF disposal. The advantages of the Yucca Mountain site may be offset by its principal drawback - the fact that over geologic time, the area and the Great Basin region have experienced earthquakes and volcanic activity.

Each year, a comprehensive analysis of the total system life-cycle cost (TSLCC) of the radioactive waste management system is performed by DOE's Office of Civilian Radioactive Waste Management (DOE 1986a, 1990a). Table 15 provides the results of the TSLCC estimates for SNF disposal published in December 1990 (DOE 1990b). The costs are broken down into four major components: development and evaluation (D\&E) cost, first repository cost, second repository cost, and benefit payments. The D\&E cost component includes all of the siting, preliminary design, development, testing, regulatory compliance, and institutional activities for the disposal program. The majority of the D\&E cost is a result of siting $(\sim 11 \%)$ and project management $(\sim 8 \%)$. Both the first and second repository cost components include the engineering, construction, closure, and decommissioning of the surface facilities and underground repository (the functions of the surface facilities are to receive the SNF and prepare it for permanent disposal underground). The largest components of the repository cost are the surface facilities ( $34 \%)$, underground excavations $(\sim 20 \%)$, and waste packages $(\sim 20 \%)$. The costs for the first repository are based on criteria for a tuff disposal repository such as the one that would be built at Yucca Mountain. The costs for the second repository, however, are based on assumed generic geologic conditions, because the location of the second repository is uncertain. The benefit payments component includes payments to the individual states or affected Indian tribes hosting the repository. Because 
TABLE 15 Unit Costs for Disposal of Spent Nuclear Fuel as a Function of Number of Repositories ${ }^{a}$

\begin{tabular}{|c|c|c|}
\hline Component & One Repository ${ }^{b}$ & Two Repositories $^{c}$ \\
\hline \multicolumn{3}{|l|}{ Life-cycle cost $\left(10^{9} \$\right)$} \\
\hline Development and evaluation & $11: 54$ & $14.76-14.96$ \\
\hline First repository & 8.41 & $6.71-6.92$ \\
\hline Second repository & NA & $6.12-6.88$ \\
\hline Benefit payments & 0.69 & $0.8-0.81$ \\
\hline Total system & 20.63 & $28.38-29.58$ \\
\hline Disposal capacity (t HM) & 87,425 & $87,425-97,525$ \\
\hline Unit disposal cost $(\$ / \mathrm{kg} H M)$ & $\sim 236$ & $\sim 325-302$ \\
\hline \multicolumn{3}{|c|}{$\begin{array}{l}\text { a Costs are given in beginning-of-year } 1994 \text { dollars. } \mathrm{NA}=\text { not } \\
\text { applicable; } \mathrm{t}=\text { metric ton; } \mathrm{HM}=\text { heavy metal. }\end{array}$} \\
\hline \multicolumn{3}{|c|}{ b Assuming 65 years of operation (fiscal year 2010 to 2075). } \\
\hline \multicolumn{3}{|c|}{ c Assuming 84 years of operation (fiscal year 2010 to 2094). } \\
\hline \multicolumn{3}{|l|}{ Source: DOE (1990b). } \\
\hline
\end{tabular}

the implementation schedules for the two repositories are not known, the cost components have not been discounted.

It is assumed that for a single repository, the capacity of the repository would be increased to accept a no-new-orders (for nuclear reactors), end-of-life projection of 96,300 t HM (which includes 8,875 t $\mathrm{HM}$ of defense-related $\mathrm{HLW}$ in addition to the $87,425 \mathrm{t} \mathrm{HM}$ of SNF). It is assumed that for a two-repository system, 70,000 $\mathrm{t} \mathrm{HM}$ would be disposed of at the first repository and the remaining waste would be emplaced in a second repository. The upper reference case (which assumes that licenses for $70 \%$ of the existing nuclear power plants are renewed for an additional 20 years) for the SNF projection is 106,400 $\mathrm{t} \mathrm{HM}$ (which includes 8,875 $\mathrm{t} \mathrm{HM}$ of defense-related HLW in addition to the $97,525 \mathrm{t}$ HM of SNF).

The results shown in Table 15 indicate that the unit cost for disposing of SNF at a single repository with a capacity of $87,425 \mathrm{t} \mathrm{HM}$ would be about $\$ 236 / \mathrm{kg} \mathrm{HM}$. For the tworepository system, in which the amount disposed of in the first repository would be limited to $70,000 \mathrm{t} \mathrm{HM}$, the unit cost for disposing of SNF at the first repository would be $\$ 302 / \mathrm{kg} \mathrm{HM}$. The unit cost for disposing of SNF at the second repository would be about $\$ 325 / \mathrm{kg} \mathrm{HM}$ and would strongly depend on the capacity of the second repository. 


\subsection{TRANSPORTATION}

Transportation of SNF is an integral component of radioactive waste management (DOE 1988b). NWPA (U.S. Congress 1983) authorized DOE to establish a national program for the management and permanent disposal of commercial SNF and HLW. A primary element of the program (DOE 1986b) is the development of the transportation system to support this program, so that DOE can accept commercial waste from nuclear power reactors or other waste generator sites for transportation to a geologic repository or an intermediate storage facility.

Transportation costs are based on current understanding of how SNF would be transported from reactor and defense sites to a repository or MRS facility (DOE 1989b). Until the final design of the transportation system is certain and transportation cost algorithms are developed, the data represent rough order-of-magnitude costs. The most acceptable and successful mode of transport is by truck or rail. Transport by air and barge is limited and generally not considered a viable option. Costs for transportation by rail or truck depend on a number of factors: origin and destination of shipments; specific route used; volume of waste shipped; shipping cask characteristics; estimates of cask processing, handling, and turnaround times; security measures; and demurrage costs associated with loading and unloading periods (Callagher 1988). The overall cost estimating methodology for the transportation system considers the (1) capital cost of purchasing or leasing the transportation casks and conveyances; (2) cask maintenance facility costs; (3) surcharges; (4) shipping inspection and detention costs; and (5) security costs. Shipping costs (i.e., shipping, surcharge, inspection, and detection) account for $40 \%$ of the total transportation estimate, the shipping cask capital and maintenance costs account for about $33 \%$, the cask maintenance facility accounts for $21 \%$, and security costs represent $6 \%$.

Studies (McCartney and Cairns 1984) have determined that costs for transportation for a one-way distance of 1,500 miles (mi) would be $\$ 36.10 / \mathrm{kg}$ U by truck if a NAC-1 cask were used and $\$ 40.50 / \mathrm{kg}$ U by rail if an IF-300 cask were used.

More recent studies (DOE 1990b) of TSLCC estimates - based on assumptions for a (1) single-repository case with no new orders, (2) two-repository case with no new orders, and (3) two-repository case that is based on the upper reference case - result in transportation costs of $\$ 36.70 / \mathrm{kg} \mathrm{U}, \$ 34.30 / \mathrm{kg} \mathrm{U}$, and $\$ 31.70 / \mathrm{kg} \mathrm{U}$, respectively. On the basis of an average one-way distance of approximately $2,300 \mathrm{mi}$ to the first repository (DOE 1991a), the unit cost for the single-repository case with no new orders is $\$ 0.14 / \mathrm{kg} \mathrm{U}$ per mile. If the distance to the second repository is assumed to be about the same, the unit transportation costs are estimated to be $\$ 0.13 / \mathrm{kg} \mathrm{U}$ per mile for the two-repository case with no new orders and $\$ 0.12 / \mathrm{kg} \mathrm{U}$ per mile for the two-repository case based on the upper reference case.

A number of reports and studies (Lilly 1986; McNair et al. 1986; Battelle Nuclear Systems Group 1989) present more detailed information on costs for transportation by rail or truck that are determined on the basis of factors that include shipping distances (one way and round trip), loading capacities, cask designs, and shipping requirements. 


\section{HIGH-LEVEL WASTE}

As defined by NWPA (U.S. Congress 1983), high-level waste (HLW) is (1) the highly radioactive material resulting from the reprocessing of SNF, including the liquid waste produced directly during reprocessing and any solid material derived from such liquid waste that contains fission products in sufficient concentrations, or (2) other highly radioactive material that the NRC, consistent with existing law, determines by rule to require permanent isolation. Proper handling and storage of HLW are required by DOE Order 5280.2A. The order also requires each generator of HLW to develop the technology for its permanent disposal in a federal repository, when one becomes available. HLW is currently stored in an interim fashion in underground tanks. DOE's approach for ending this interim storage of $\mathrm{HLW}$ is to transform the part that is highly radioactive into a more stable glass form by vitrification and then ship the vitrified glass product to a geologic repository for permanent disposal.

\subsection{TREATMENT}

Since the present thinking is to dispose of liquid HLW in solid form, calcination and vitrification have been considered among the general methods of immobilization. Vitrification is the preferred method because of the advantage offered by glass as the final storage form (Belter 1963). Treating $\mathrm{HLW}$ is a multistep process (GAO 1993). The waste is first characterized to determine its physical, chemical, and radioactive composition. This characterization is performed so that the HLW can be safely and effectively retrieved, pretreated, and treated. The waste is then retrieved from interim storage by pumping or other means and sent to a pretreatment facility. In pretreatment, the high-activity fraction of the waste is separated from the low-activity fraction and from nonradioactive elements, such as aluminum, organic compounds, and salts. This step is desirable because it decreases the volume of waste that must be vitrified. The low-activity waste, which makes up about $90 \%$ of the tank waste, is considered either low-level waste (LLW) or low-level mixed waste (MW). It is treated by being mixed with cementitious materials (the grouting process) and disposed of on-site. The high-activity waste is vitrified (immobilized) by being mixed with glass-forming materials at high temperatures. This process produces glass logs that are sealed in canisters. A glass made of boron and silicon (i.e., borosilicate glass) was chosen as the protective material for HLW immobilization because it (1) has long-term stability, (2) is strong enough to resist the stresses of being disposed of in a repository; (3) can withstand leaching under conditions that could exist in a repository, and (4) is suitable for large-scale, remote operations with highly radioactive waste.

Since the early 1980 s, DOE has been constructing various facilities to treat and dispose of the HLW stored at the Savannah River Site (SRS) in South Carolina. The major facility that will be involved in treating SRS HLW is the Defense Waste Processing Facility (DWPF) at SRS. It will process $\mathrm{HLW}$ into a solid form suitable for permanent disposal by dissolving radioactive sludge in molten borosilicate glass. The product will then be poured into stainless-steel canisters. Before being vitrified, the waste will undergo two major 
pretreatment processes. One will separate the high-activity fraction of the waste from the low-activity fraction. The second will remove explosive organics (mainly benzene) from the waste going into the vitrification process. The capital and operating costs of HLW treatment at SRS (BOY 1994 dollars) are shown in Table 16 (GAO 1992b; Street et al. 1992).

When the DWPF becomes operational, DOE estimates it will take about 17 years before all the HLW waste is vitrified. The TSLCC is estimated to approach $\$ 7.1$ billion (BOY 1994 dollars). A total of 5,282 vitrified glass canisters are projected to be generated during the 17 years of operation, with each canister containing approximately 9,014 gallons of SRS HLW (Choi and Fowler 1990, appendix G, table 19.1). On the basis of these assumptions, the unit cost of HLW treatment is expected to be about $\$ 147$ per gallon of HLW.

In the literature, however, a unit treatment cost of $\$ 26.29$ per gallon of SRS HLW has been estimated (Street et al. 1992). This value is lower because in Streets et al., the cost of the existing HLW treatment facilities at SRS is considered "sunk" (i.e., already incurred), and it is assumed this cost will not affect current or future waste generation and/or treatment. Exclusion of these sunk costs does not allow a full-cost-recovery determination for the TSLCC.

The DOE also plans to construct a facility similar to the DWPF for the Hanford Site in Washington. This facility is to be called the Hanford Waste Vitrification Plant (HWVP). Only very broad estimates of the TSLCC for HLW treatment at Hanford can be found in the literature. One recent report placed it between $\$ 25$ and $\$ 45$ billion. This estimate included costs for research and development, waste characterization, waste pretreatment and facilities, vitrification facility design and construction, on-site canister storage facilities, and operations and other capital costs necessary to prepare and store the $\mathrm{HLW}$ pending its shipment to a geologic repository (GAO 1993). Retrieval, however, was not mentioned. The cost to retrieve the HLW in the double-shell tanks (DSTs) and single-shell tanks (SSTs) has been projected

TABLE 16 Capital and Annual Operating Costs for Treatment of High-Level Waste at the Savannah River Site ${ }^{a}$

\begin{tabular}{lr} 
Capital costs $\left(10^{6} \$\right)$ & 97 \\
In-tank precipitation & 2,250 \\
DWPF & 83 \\
Interim canister storage & 1,730 \\
Other DWPF support facilities & 168 \\
Annual operating cost $\left(10^{6} \$\right)$ & \\
\hline & \\
a Costs are given in beginning-of-year & \\
1994 dollars. DWPF = Defense Waste \\
Processing Facility
\end{tabular}

Sources: GAO (1992b); Street et al. (1992). 
to exceed $\$ 16$ billion (BOY 1994 dollars). The latest numbers indicate that the TSLCC for the HLW at Hanford could approach $\$ 53$ billion (BOY 1994 dollars). The current HLW inventory at Hanford includes $36 \times 10^{6}$ gal of SST waste and $25 \times 10^{6}$ gal of DST waste, for a total of $61 \times 10^{6} \mathrm{gal}$. The unit cost of HLW treatment at Hanford will therefore be about $\$ 860$ per gallon of $\mathrm{HLW}$ ( $\$ 53$ billion per $61 \times 10^{6} \mathrm{gal}$ of $\mathrm{HLW}$ ).

The West Valley Demonstration Project is being undertaken at the Western New York Nuclear Services Center. The objective is to conduct an HLW management operation to immobilize the 660,000 gallons of HLW stored on-site. Construction of the vitrification facility began on August 12, 1985, and was completed during fiscal year (FY) 1994. Currently, the West Valley Demonstration Project is reducing the 660,000-gal volume by decontaminating the supernatant phase by ion exchange and washing and by decontaminating the underlying sludge phase. Vitrification operations that will use the HLW at West Valley are expected to take place from 1996 to 1998, during which a total of $300 \mathrm{HLW}$ canisters will be produced. The funding support for FY 1991 to FY 1997 is projected to approach $\$ 869$ million (DOE 1991a), with a FY 1997 operating budget of $\$ 142$ million during vitrification operations (BOY 1994 dollars). On the basis of an estimated capital cost of $\$ 530$ million and a cost of $\$ 142$ million per year for operations over 3 years, the (undiscounted) TSLCC cost will be approximately $\$ 0.9$ billion. The unit cost of HLW treatment at West Valley will be about $\$ 1,440$ per gallon of HLW (BOY 1994 dollars).

A comparison of unit treatment costs as a function of DOE site is given in Table 17. Unit treatment costs range from $\$ 147$ to $\$ 1,440$ per gallon of HLW because of the differences in physical form, chemical constituents, amount to be treated, annual processing rate, and other variables. The high unit treatment cost of HLW relative to other radioactive waste categories such as LLW and MW results from the remote operations and heavy protective shielding required to confine penetrating radiation. When considered on an unit canister basis, however (see Table 16), the treatment cost ranges from only $\$ 1.4$ to $\$ 3.8$ million per

TABLE 17 Unit Costs for Treatment of High-Level Waste at Various DOE Sites $^{\text {a }}$

\begin{tabular}{lccc}
\hline & & \multicolumn{2}{c}{ Unit Treatment Cost } \\
\cline { 3 - 4 } \multicolumn{1}{c}{ DOE Site } & $\begin{array}{c}\text { Total Projected No. } \\
\text { of Canisters }\end{array}$ & $\begin{array}{c}\text { Per Gallon } \\
(\$)\end{array}$ & $\begin{array}{c}\text { Per Canister } \\
\left(10^{6} \$\right)\end{array}$ \\
\hline Savannah River & 5,282 & 147 & 1.4 \\
Hanford & $14,000-37,000$ & 863 & $1.5-3.8$ \\
West Valley & 300 & 1,440 & 3.2 \\
\hline
\end{tabular}

a Costs are given in beginning-of-year 1994 dollars.

Sources: Street et al. (1992); DOE (1991a); GAO (1992a, 1993). 
HLW canister. This small range indicates that most of the capital equipment and operating costs are associated with the vitrification process as opposed to other unit operations such as retrieval, pretreatment, or interim canister storage.

\subsection{STORAGE}

Spent nuclear fuel for defense purposes was reprocessed at three sites: SRS, Idaho National Engineering Laboratory (INEL), and the Hanford Site. SNF from commercial purposes was reprocessed at West Valley, New York. Most of the present inventory of HLW is the result of DOE activities and is stored at SRS, INEL, and Hanford (DOE 1992a). The HLW generated at West Valley, New York, resulted from the operation of the world's first commercial fuel reprocessing plant. This plant reprocessed $650 \mathrm{t}$ U SNF over 7 years (1966 to 1972). Most of the wastes at these sites have already undergone one or more treatment steps (e.g., neutralization, precipitation, evaporation) and are not in the same form as they were when initially generated or characterized. At SRS and Hanford, liquid HLW has generally been neutralized and stored in underground tanks. At INEL, liquid HLW is calcined to a free-flowing granular solid (calcine) and stored in stainless-steel tanks. Most of these wastes will require incorporation into a stable, solid medium (e.g., glass) for final disposal (Hench 1984). The total volume of $H L W$ at the end of 1991 was $3.966 \times 10^{5} \mathrm{~m}^{3}$, at a total radioactivity of $9.969 \times 10^{8}$ curies (Ci). DOE intends to begin vitrification of some of the current inventory; therefore, the total cumulative volume of stored HLW at the end of the year 2000 is projected to be $3.34 \times 10^{5} \mathrm{~m}^{3}$, at a total radioactivity of $9.93 \times 10^{8} \mathrm{Ci}$.

The unit cost of HLW storage was estimated on the basis of data on annual operating costs from SRS, Hanford, and INEL. It was assumed that no capital investments would be required in the near term, so the only relevant costs would be those from annual operations. Including costs for tank farm upgrades and the construction of new tanks or for the final decontamination and decommissioning of tank farms would increase the unit storage cost to more than the amount reported on in this section.

Through 1991, SRS accumulated about $34 \times 10^{6} \mathrm{gal}\left(1.279 \times 10^{5} \mathrm{~m}^{3}\right)$ of HLW with a radioactivity of about $5.38 \times 10^{8} \mathrm{Ci}$. This $\mathrm{HLW}$ is presently being stored in underground, double-walled, carbon steel tanks. These figures represent about $33 \%$ of the total volume of $\mathrm{HLW}$ and about $54 \%$ of the existing total $\mathrm{HLW}$ radioactivity at all sites (DOE 1992a). This current inventory of HLW at SRS includes alkaline liquid, salt cake, sludge, and precipitate that was generated primarily by the reprocessing of nuclear fuels and targets from production reactors. The unit cost of operating the HWW tank farms at SRS is determined by dividing their annual operating cost of about $\$ 168$ million (Street et al. 1992) by the total HLW inventory of $34 \times 10^{6} \mathrm{gal}$. On the basis of these assumptions, the annual unit cost of storing HLW at SRS was estimated to be $\$ 5.5$ per gallon (BOY 1994 dollars).

The Hanford Site began storing $\mathrm{HLW}$ in underground tanks in 1944 . The waste came from a variety of sources, including plutonium and uranium recovery from irradiated SNF. Hanford HLW is mainly contained in 177 underground storage tanks built between 1943 and 1986. The capacities of these tanks range from 55,000 to more than $1 \times 10^{6}$ gal. 
Approximately $61 \times 10^{6} \mathrm{gal}$ of $\mathrm{HLW}$ are stored at the Hanford Site, which represents about $63 \%$ of the total HLW volume and about $37 \%$ of the total $\mathrm{HLW}$ radioactivity. The 177 underground tanks at Hanford are of two basic types. The oldest 149 tanks are of singleshell construction; they have a single-layer steel wall encased within a concrete shell. Of these tanks, 67 are known or suspected to have leaked waste into the environment. The newest 28 tanks are of double-shell construction; they have two steel layers instead of one. The waste at Hanford is stored in four main forms: sludge, salt cake, slurry (combination of liquid and suspended solid waste), and liquid. The total funding for the waste tank safety and operations program at Hanford was reported to be $\$ 166.8$ million for FY 1992 (GAO 1992a); the HLW inventory at that time was $24.528 \times 10^{6}$ gal of DST waste and $36.239 \times 10^{6} \mathrm{gal}$ of SST waste for a total of $60.767 \times 10^{6} \mathrm{gal}$ (DOE 1992a). The yearly unit storage cost is therefore $\$ 2.8$ per gallon of HLW (BOY 1994 dollars). A Westinghouse Hanford Company study determined that operating the tank farms in compliance with DOE and industry standards for a year would require $\$ 262$ million (GAO 1992a); this figure equates to a yearly unit storage cost of $\$ 4.5$ per gallon of HLW (BOY 1994 dollars). The yearly unit storage cost at Hanford therefore ranges between $\$ 2.8$ and $\$ 4.5$ per gallon of HLW (BOY 1994 dollars).

The HLW generated during reprocessing at INEL initially took the form of an acidic liquid. In 1963, INEL began to calcine this waste into a dry, granular solid. This solid waste is stored in stainless-steel bins housed in reinforced concrete vaults with an expected lifetime of at least 500 years. The liquid waste is stored in underground stainless-steel tanks enclosed by concrete vaults. The acidic liquid portion of the INEL HLW represents the majority (about 65\%) of the total INEL HLW volume but only a fraction (about 4\%) of the total INEL HLW radioactivity. INEL is unique in that it stores HLW in both liquid and solid forms. Funding allocated during FY 1991 for HLW tank farm/calcine storage was reported to $\$ 2.59$ million (Albuquerque Field Office 1991). The inventory at INEL during 1991 was $6,800 \mathrm{~m}^{3}$ of liquid $\mathrm{HLW}$ and $3,600 \mathrm{~m}^{3}$ of solid calcine, for a total of $10,400 \mathrm{~m}^{3}$ (equivalent to $\left.2.75 \times 10^{6} \mathrm{gal}\right)$. The yearly unit storage cost at INEL is estimated to be $\$ 0.90$ per gallon of HLW (BOY 1994 dollars). This estimate assumes that the calcine requires the same level of management as liquid HLW, which may not be correct because calcine's more stable form may require less surveillance.

A comparison of the individual unit storage cost values is given in Table 18. The unit storage costs range from $\$ 0.9$ to $\$ 5.5$ per gallon of HLW. This comparatively small range is remarkable, given the differences in physical form, amount in storage, etc.

\subsection{DISPOSAL}

The permanent disposal of $\mathrm{HLW}$ is a complex undertaking that could affect not only the present generation but also generations to come. Disposal involves the final emplacement of the immobilized waste so as to ensure isolation from the surrounding environment for tens of thousands of years, until it is no longer dangerously radioactive. Our nation's long-term waste management goal is to end $\mathrm{HLW}$ storage and begin its permanent disposal (DOE 
TABLE 18 Unit Costs for Storage of High-Level Waste at the Three Main DOE Sites ${ }^{2}$

\begin{tabular}{lccc}
\hline DOE Site & $\begin{array}{c}\text { Annual } \\
\text { Storage Cost } \\
\left(10^{6} \$\right)\end{array}$ & $\begin{array}{c}\text { HLW } \\
\text { Inventory } \\
\left(10^{6} \text { gal }\right)\end{array}$ & $\begin{array}{c}\text { Annual Unit Storage Cost } \\
(\$ / \text { gal HLW })\end{array}$ \\
\hline Savannah River & 162 & 32 & 5.5 \\
Hanford & $167-262$ & 60.767 & $2.8-4.5$ \\
INEL & 2.59 & 2.75 & 0.9 \\
\hline
\end{tabular}

a Costs are given beginning-of-year 1994 dollars. INEL = Idaho National Engineering Laboratory.

Sources: Albuquerque Field Office (1991); DOE (1992a); Street et al. (1992).

1991b). DOE plans to temporarily store the canisters containing the high-activity fraction of the waste until an underground repository is ready to receive them permanently (GAO 1993).

The method for disposal of HLW being given the most serious consideration is emplacement in a stable geologic medium. Presently, the Yucca Mountain site in Nevada is undergoing characterization that could result in its being the first U.S. HLW repository. It is expected to accept 70,000 t HM of SNF or its equivalent of $\mathrm{HLW}$. The present plan is for the HLW to be contained in primary sealed canisters, which will then be loaded into sealed secondary containers (overpacks). The containers will be emplaced in bore holes in an engineered system of multilayered underground barriers.

Each year, a comprehensive analysis of the TSLCC of the radioactive waste management system is performed by DOE's Office of Civilian Radioactive Waste Management (DOE 1986a, 1990a). Table 19 provides the results of the TSLCC estimates for HLW disposal published in DOE (1990a). The costs have been broken down into four major cost components: D\&E, first repository, second repository, and benefit payments. The D\&E cost component includes all of the siting, preliminary design, development, testing, regulatory compliance, and institutional activities for the disposal program. The majority of the D\&E cost is due to siting $(\sim 11 \%)$ and project management $(\sim 8 \%)$. The repository cost component includes the engineering, construction, closure, and decommissioning of the surface facilities and underground repository. The function of the surface facilities is to receive the SNF and prepare it for permanent disposal underground. The largest components of the repository cost are the surface facilities ( 34\%), underground excavations $(\sim 20 \%)$, and waste packages $(\sim 20 \%)$. The costs given in Table 19 are estimated on the basis of the tuff disposal criteria currently being considered for the first repository. However, the costs for the second repository are estimated on the basis of assumed generic geologic conditions, because the location of the second repository is not certain. The final cost component deals with benefit payments to be made to the individual states or affected Indian tribes that will host the repository. Because the implementation schedules for the two repositories are not known, the cost components have not been discounted. 
TABLE 19 Unit Costs for Disposal of High-Level Waste as a Function of Number of Repositories ${ }^{\mathrm{a}}$

\begin{tabular}{|c|c|c|}
\hline Component & One Repository ${ }^{b}$ & Two Repositories ${ }^{c}$ \\
\hline \multicolumn{3}{|l|}{ Life-cycle cost $\left(10^{9} \$\right)$} \\
\hline Development and evaluation & 2.09 & $3.04-2.88$ \\
\hline First repository & 1.93 & $1.57-1.41$ \\
\hline Second repository & NA & $1.64-1.76$ \\
\hline Benefit payments & 0.092 & $0.14-0.13$ \\
\hline Total system & 4.11 & $6.39-6.17$ \\
\hline \multicolumn{3}{|l|}{ Disposal capacity } \\
\hline In $t H^{d}$ & 8,875 & 8,875 \\
\hline In no. of canisters & 17,750 & 17,750 \\
\hline \multicolumn{3}{|l|}{ Unit disposal cost } \\
\hline In $\$ / \mathrm{kg} \mathrm{HM}$ & $\sim 464$ & $\sim 720-696$ \\
\hline In $10^{3} \$ /$ canister & $\sim 232$ & $-360-348$ \\
\hline \multicolumn{3}{|c|}{$\begin{array}{l}\text { a Costs are given in beginning-of-year } 1994 \text { dollars. } N A=\text { not } \\
\text { applicable; } t=\text { metric ton; } H M=\text { heavy metal. }\end{array}$} \\
\hline \multicolumn{3}{|c|}{ b Assuming 65 years of operation (fiscal year 2010 to 2075). } \\
\hline \multicolumn{3}{|c|}{ c Assuming 84 years of operation (fiscal year 2010 to 2094). } \\
\hline \multicolumn{3}{|c|}{$\mathrm{d}$ On the basis of $0.5 \mathrm{t} \mathrm{HM}$ per canister. } \\
\hline Source: DOE (1990a). & & \\
\hline
\end{tabular}

The results shown in Table 19 indicate that the unit cost for disposing of HLW in a single repository with a capacity of $8,875 \mathrm{t} \mathrm{HM}$ would be about $\$ 464 / \mathrm{kg} \mathrm{HM}$. For the tworepository system, in which the capacity of the first repository would be $8,875 \mathrm{t} \mathrm{HM}$, the unit cost for disposing of $\mathrm{HLW}$ in the first repository would be the same as that for disposal at a single repository, or $\$ 464 / \mathrm{kg} \mathrm{HM}$. For the two-repository system, the unit cost for disposing of $\mathrm{HLW}$ at the second repository would range from $\$ 696$ to $\$ 720 / \mathrm{kg} \mathrm{HM}$, depending on the total capacity of both repositories, which would include both SNF and HLW (see Section 5.3). The results shown in Table 19 further indicate that the unit cost for disposing of HLW determined on the basis of the total number of $\mathrm{HLW}$ canisters emplaced in a single repository is approximately $\$ 232,000$ per canister. This estimate agrees closely with the unit cost of $\$ 211,000$ per canister reported in Street et al. (1992) for the life-time cost of isolating HLW canisters in a single geologic repository.

\subsection{TRANSPORTATION}

Numerous reports agree that transportation costs for HLW would be similar to those for SNF (Bixby 1987; DOE 1991c). A unit cost of $\$ 10,500$ per canister (BOY 1994 dollars) for transportation by truck has been quoted in DOE (1990a); this estimate assumes that a total 
of 17,750 canisters of $\mathrm{HLW}$ from defense operations would be shipped from the three major HLW sites (Hanford, INEL, and SRS) to the first repository.

The total transportation cost for shipping the $17,750 \mathrm{HLW}$ canisters is estimated to be $\$ 297$ million (1988 dollars) (DOE 1990a). The estimated total number of canister-miles is given in Table 20. The estimate is determined on the basis of the distribution of canisters among the three HLW defense sites and the distance of the individual sites to the first repository.

The unit transportation cost per canister-mile is estimated by using the following calculation:

$$
\begin{aligned}
\text { Unit transportation cost } & =\left[\left(\$ 297 \times 10^{6}\right) /\left(2.564 \times 10^{7} \text { canister-mi }\right)\right] \times 1.184 \\
& =\$ 13.5 / \text { canister-mi }
\end{aligned}
$$

where the factor 1.184 converts 1988 dollars to BOY 1994 dollars.

TABLE 20 Total Number of Canister-Miles for Transportation of High-Level Waste to the First Repository

\begin{tabular}{lrcr}
\hline Defense Site & $\begin{array}{c}\text { No. of HLW } \\
\text { Canisters }\end{array}$ & $\begin{array}{c}\text { Distance to First } \\
\text { Repository (mi) }\end{array}$ & $\begin{array}{c}\text { Millions of } \\
\text { Canister-Miles }\end{array}$ \\
\hline Hanford & 1,500 & & \\
INEL & 10,650 & 1,302 & 1.95 \\
Savannah River & 5,600 & 756 & 8.05 \\
Total & 17,750 & 2,792 & 15.64 \\
\hline
\end{tabular}




\section{LOW-LEVEL WASTE}

Low-level waste (LLW) is a term generally assigned to materials that are excluded from other waste categories. Thus, it is defined as radioactive waste that is not SNF, HLW, TRU waste, or by-product material specified as uranium or thorium tailings or waste. LLW often has relatively little radioactivity and contains practically no transuranic elements. Most LLW requires little or no shielding and may be handled by direct contact. The radioactivity of some $L L W$, however, is high enough that the LLW requires special treatment and disposal. This type of LLW is referred to as intermediate low-level waste (DOE 1987b; Stelluto 1991).

Low-level waste comes in three physical forms: liquids, wet solids, and dry solids. Liquids are fluids that have been contaminated with radioactive materials such as decontamination solutions and liquid scintillators. Wet solids are relatively thick slurries containing a certain fraction of solids such as spent ion-exchange resins. Dry solids are trash, contaminated clothing, and irradiated equipment (Roles 1990).

Packages of LLW that may be buried in near-surface disposal sites can also be divided into three classes - A, B, and C - according to the type, activity, concentration, and the half-lives of the nuclides. These LLW classes are applicable only to waste that is regulated by the NRC. In general terms, Class A waste is the least radioactive; during the institutional control period after the site is closed, Class A waste will decay to levels that are generally considered not dangerous. Class $\mathrm{B}$ waste is more radioactive than Class $\mathrm{A}$ and must be kept away from the public for up to 300 years. Class $\mathrm{C}$ waste has the maximum radioactivity allowed for near-surface burial; it must be isolated for more than 300 years and may require burial at greater depths than Class A or B (Williams 1983).

Currently, all LLW generated by DOE activities must be buried at one of six authorized DOE sites: Hanford Site, INEL, Los Alamos National Laboratory (LANL), Nevada Test Site, Oak Ridge Reservation, or SRS. More than 30 sites within the DOE complex generate LLW (DOE 1992a). In 1991, approximately $75,845 \mathrm{~m}^{3}$ of LLW (containing $448,680 \mathrm{Ci}$ ) was generated within DOE. Another $26,639 \mathrm{~m}^{3}$ of LLW (containing $88,666 \mathrm{Ci}$ ) was in storage, and about $53,520 \mathrm{~m}^{3}$ of LLW (containing $717,597 \mathrm{Ci}$ ) was buried. Of the six disposal sites, SRS both generated and disposed of the largest volume of LLW in 1991 (approximately $34 \%$ and $44 \%$, respectively). SRS and Hanford receive the largest volume of wastes from off-site. In 1991, they disposed of the second and third largest quantities of LLW (22\% and 20\%, respectively) (DOE 1992a; English 1991).

Three commercial LLW disposal facilities are currently in operation. The Barnwell, South Carolina, disposal facility is operated by Chem-Nuclear Systems, Inc. The Richland, Washington, and Beatty, Nevada, facilities are operated by U.S. Ecology, Inc. (Roles 1990). Gross volume and activity distribution data for the three disposal facilities for 1987 through 1989 indicate that the total annual volume of waste disposed of ranged from a low of 1.4 $\times 10^{6} \mathrm{ft}^{3}$ in 1988 to a high of $1.85 \times 10^{6} \mathrm{ft}^{3}$ in 1987 . Therefore, over this period, the waste 
volume varied over a range of about $4.2 \times 10^{5} \mathrm{ft}^{3}$. The total waste radioactivity reported was 270,000 Ci during 1987 and 870,000 Ci during 1988.

The fractional distribution of the waste volume among the three waste classes has been similar for the last 3 years. Class A waste makes up 96-97\% of the volume, Class B waste $2-3 \%$, and Class $\mathrm{C}$ waste $0.5-1 \%$. The Barnwell facility consistently received more than half of the waste volume and more than three-quarters of the waste radioactivity (Roles 1990).

\subsection{TREATMENT}

An increasingly important aspect of treating LLW is to reduce its volume to the lowest practicable level to minimize ultimate disposal and transportation costs (Electric Power Research Institute 1988a,b). These costs are assessed on a unit volume basis and have been increasing yearly. Therefore, all types of LLW are often subject to treatment (i.e., volume reduction) and/or conditioning (i.e., waste immobilization) before disposal. This area of $L L W$ waste management, having been established and proven over the past 35 years, is considered to be quite mature in terms of technology development and has been found to be cost effective (Williams 1983). As a result, several effective, safe, and feasible treatment and conditioning options exist for LLW (Eberhart et al. 1986). Treatment options include storage and decay, compaction and supercompaction, incineration, chemical precipitation, evaporation, filtration, and ion-exchange. Conditioning options such as immobilization in materials like concrete, bitumen, or polymers may follow.

Volume reduction has largely been achieved by mechanical compaction, evaporation, incineration, and solidification. The bulk density of solid LLW is, on average, $160-240 \mathrm{~kg} / \mathrm{m}^{3}$ $\left(10-15 \mathrm{lb} / \mathrm{ft}^{3}\right)$. The compacted forms may have a density greater than $1,000 \mathrm{~kg} / \mathrm{m}^{3}$. Some systems presently available combine evaporation, compaction, and incineration in one process stream.

The extent of volume reduction basically determines the amount of waste that will have to be stored, transported, and buried. It also influences the specific activity $\left(\mathrm{Ci} / \mathrm{ft}^{3}\right)$ of the processed waste. Volume reduction increases the surface dose rate of the container. Therefore, a greater extent of volume reduction generally offers a short-term decrease in the overall unit cost. However, the higher surface dose rate it causes affects occupational exposure levels and can lead to environmental concerns, which may result in increased longterm costs.

Recent studies by Kalb and Fuhrmann (1992) and Wiemers (1992) indicate that polyethylene encapsulation is an improved process for solidifying LLW and MW that are not satisfactorily treated by conventional solidification technologies. Polyethylene is an inert thermoplastic material that can be processed at relatively low temperatures $\left(130-150^{\circ} \mathrm{C}\right)$ and combined with waste to form a homogenous molten mixture. Upon cooling, the mixture forms a monolithic solid waste form with excellent properties for disposal. The polyethylene encapsulation method can significantly reduce the volume of waste, resulting in large overall 
cost savings. However, full-scale demonstration studies need to be performed and thermal and radiation stability tests need to be conducted before this method's potential economic advantage over existing solidification technologies can be established.

Interest in incinerating combustible LLW, such as paper and clothing trash, is increasing because much higher volume reduction factors can be achieved. Advanced incineration facilities are achieving volume reduction ratios of up to 100:1. The ashes that result from the process have a chemical composition that immobilizes radioactivity. They are usually solidified through the use of binders, such as cement, before being disposed of.

Evaporation, solidification, and stabilization are alternative methods for volume reduction. Their use depends on the type and volume of waste. Some commercial waste reduction systems combine evaporation, incineration, and compaction in one process stream.

Costs for treating LLW vary from a low of $\$ 105 / \mathrm{ft}^{3}$ for simple compaction, to $\$ 424 / \mathrm{ft}^{3}$ for incineration, to a high of $\$ 568 / \mathrm{ft}^{3}$ for metal melting. The volumes considered here are before treatment. The costs are average values that are strongly affected by the type, characteristics, and volume of waste treated. In this assessment, one must consider that compaction achieves volume reduction factors of only 5 to 10 , while typical incineration methods achieve volume reduction factors of up to 100 . The costs for similar treatment of alpha-emitting LLW and MW would be higher because more restrictive control technologies must be used to handle these wastes (Jacobs et al. 1984).

\subsection{STORAGE}

The uncertainty with regard to future requirements for LLW disposal has prompted the development of on-site storage options as an interim measure for handling LLW. On-site storage is also useful for providing temporary storage during short-term operational surges. Two approaches for temporary storage are presently being used. One uses shallow land trenches, the other uses above-grade storage facilities. Specially designed, stand-alone storage containers are used for the above-grade storage. Both approaches have estimated costs of $\$ 160-180 / \mathrm{ft}^{3}-\mathrm{yr}$.

\subsection{DISPOSAL}

The most common methods for disposing of LLW involve disposal in shallow earthen or concrete-lined trenches or in structures on the ground. These structures are commonly referred to as engineered surface facilities (EG\&G Idaho, Inc. 1987). Safe near-surface disposal of LLW has been practiced for almost 30 years. The rationale behind near-surface disposal is that because the isolation period needed for LLW is relatively limited (up to 300 years), institutional or administrative control of the disposal site can be ensured. Waste is typically delivered to near-surface disposal sites in metal drums or concrete containers that provide adequate protection against radioactivity and leakage problems. 
Shallow land trench disposal, without engineered features, is the most prevalent method for disposing of LLW at both DOE and commercial nuclear sites. Costs of shallow land disposal vary widely. Costs (BOY 1994 dollars) for shallow land disposal at existing facilities are summarized here.

- U.S. Ecology Washington Nuclear Center. Published basic disposal costs for solid LLW vary from $\$ 33.80$ to $\$ 51.40 / \mathrm{ft}^{3}$, depending on radiation dose ( 0.20 to 40.00 roentgen equivalent man per hour [rem $/ \mathrm{h}])$. Hanford estimated that the cost of disposal of LLW at the U.S. Ecology Center would be $\$ 72.30 / \mathrm{ft}^{3}$ with typical surcharges applied.

- U.S. Ecology Nevada Nuclear Center. Published basic disposal costs for solid LLW vary from $\$ 33.80$ to $\$ 57.90 / \mathrm{ft}^{3}$, depending on radiation dose $(0.20$ to $40.00 \mathrm{rem} / \mathrm{h})$.

- Chem-Nuclear Systems, Inc., Barnwell Low-Level Radiative Waste Management Facility. The published basic disposal cost for solid LLW is $\$ 43.20 / \mathrm{ft}^{3}$. Weight surcharges, varying from $\$ 620$ to $\$ 3,830$ per container, apply to containers weighing up to $50,000 \mathrm{lb}$.

Recently, reliance on the use of both below-grade and above-grade vaults, concrete containment, and modular concrete canister disposal methods has increased (Macbeth et al. 1979). Unit costs range from $\$ 126 / \mathrm{ft}^{3}$ for above-grade vaults, to $\$ 190 / \mathrm{ft}^{3}$ for below-grade vaults, to the expected high cost of $\$ 2,182 / \mathrm{ft}^{3}$ for specially designed engineered trenches for greater confinement of waste. Because all these facilities are only in the design stages, realistic unit costs have not been determined (EG\&G Idaho, Inc. 1987).

Figure 5 shows the actual unit costs for storing and disposal of LLW at the Hanford Site in Richland, Washington, through 1994 and the projected planning rates through 1999.

\subsection{TRANSPORTATION}

Costs for transporting LLW by truck have been estimated at $\$ 1.10$ to $\$ 3.65 / \mathrm{ft}^{3}$, depending on the distance traveled, or at $\$ 26$ per 55-gal drum or $\$ 42$ per 80 -gal drum when the LLW is transported in lots larger than 50 drums for a one-way distance of up to $500 \mathrm{mi}$. 


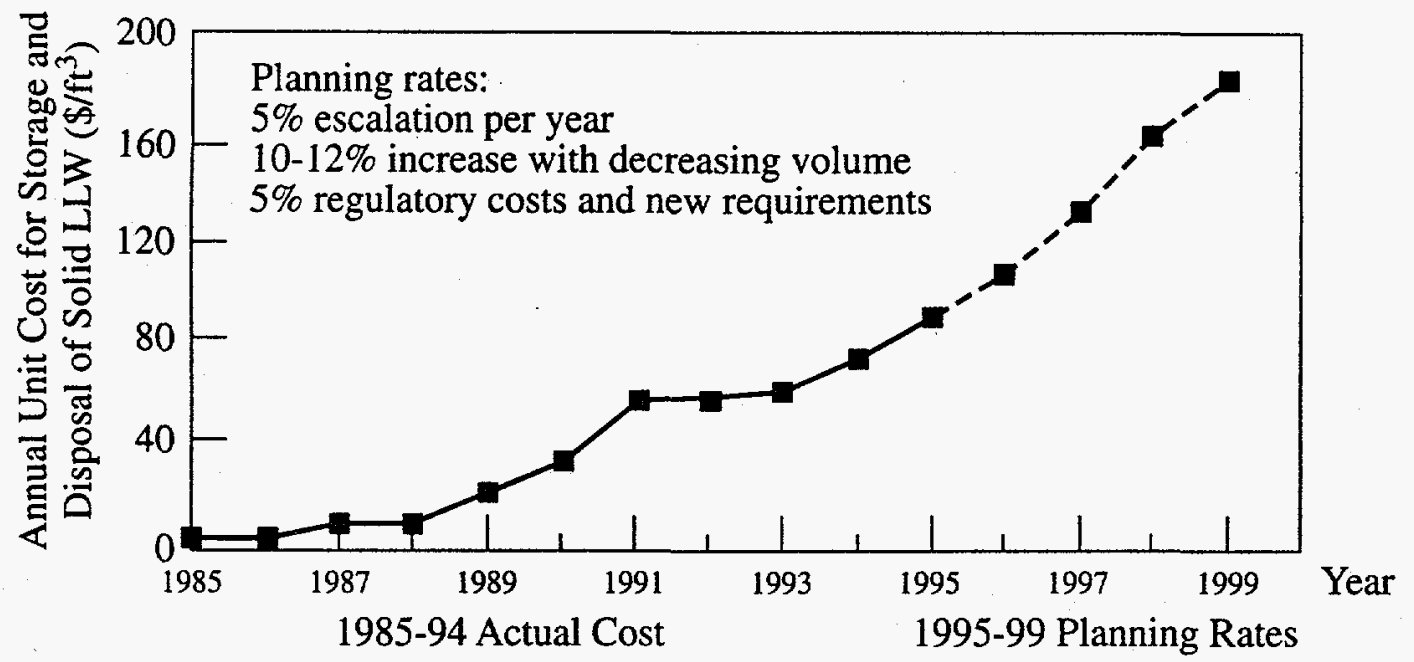

FIGURE 5 Unit Costs for Storage and Disposal of Low-Level Waste (Sources: Broomfield and Fort 1991; Hennig 1993) 


\section{TRANSURANIC WASTE}

The definition of transuranic (TRU) waste currently accepted by DOE, NRC, and EPA is waste that contains concentrations of $100 \mathrm{nCi} / \mathrm{g}$ or more of alpha-emitting TRU radionuclides with atomic numbers greater than 92 and with half-lives greater than 20 years. This definition includes isotopes of neptunium $(\mathrm{Np})$, plutonium $(\mathrm{Pu})$, americium ( $\mathrm{Am}$ ), curium $(\mathrm{Cm})$, and californium (Cf). Since there is presently no reprocessing of commercial fuel, virtually all TRU waste being generated in the United States is from defense or other government operations (DOE 1987a, 1988a).

Management activities (generation, burial, storage, and disposal) for TRU waste are performed at six major DOE sites: Hanford Site, INEL, LANL, Oak Ridge National Laboratory (ORNL), Rocky Flats Plant, and SRS. In addition to these six major DOE sites, up to 16 other DOE laboratories participate on a smaller scale (DOE 1992a).

Most TRU waste exists in solid form such as protective clothing, paper trash, rags, glass, tools, and miscellaneous equipment (Jensen 1983). Some TRU waste is in liquid form (sludges) resulting from chemical processing for recovery of plutonium. Before 1970, all DOEgenerated TRU waste was disposed of on-site in shallow, landfill-type configurations and referred to as "buried" TRU waste. Since 1970, all TRU waste has been segregated from other waste types and placed in retrievable storage. This waste is referred to as "retrievable stored" TRU waste and is stored in metal drums, wooden and metal boxes, and concrete culverts. This waste is kept in a readily retrievable form awaiting permanent disposal.

The total volume of buried DOE TRU waste through 1991 is estimated at $1.91 \times 10^{5} \mathrm{~m}^{3}$, with a total mass of $7.66 \times 10^{2} \mathrm{~kg}$ and a radioactivity level of $2.79 \times 10^{5} \mathrm{Ci}$. The total volume of retrievable stored TRU waste at the end of 1991 is $6.5 \times 10^{4} \mathrm{~m}^{3}$, with a total mass of $2.3 \times 10^{3} \mathrm{~kg}$ and a radioactivity level of $1.2 \times 10^{6} \mathrm{Ci}$. Most of the buried waste is located at the Hanford Site and INEL, while most of the retrievably stored waste is divided among Hanford, INEL, LANL, ORNL, and SRS. It is estimated that approximately 37\% of the current inventory will be reclassified and managed as LLW. A large fraction of TRU waste is mixed and contains hazardous components that are restricted from land disposal.

Plans are to ship retrievable stored TRU waste and newly generated TRU waste from defense-related activities to the Waste Isolation Pilot Plant (WIPP), a permanent geologic repository in Carlsbad, New Mexico, for final disposal. WIPP is presently being tested to ensure that it meets all federal and state disposal requirements. As of this date, no decision has been made as to the final disposition of the existing buried TRU waste.

The majority (>90\%) of TRU waste consists mainly of plutonium, which emits alpha particles and low-energy photons. Therefore, the packaging for this waste is designed to provide sufficient containment and shielding to minimize problems resulting from personnel exposure. This waste form is referred to as "contact-handled" (CH). Some TRU waste also contains activation materials and fission products that decay by beta emission and produce penetrating gamma radiation. This TRU waste is referred to as "remote-handled" (RH), if 
the radiation field at the surface of the waste package exceeds $200 \mathrm{mrem} / \mathrm{h}$. At the end of 1991, the volume of RH TRU waste was approximately $3 \%$ of the entire retrievable stored TRU waste inventory.

\subsection{TREATMENT}

The requirements for treating TRU waste depend to a large extent on the results of the WIPP analysis (Frei 1992) regarding site stability and migration. Treatment may range from minimal operations (such as packaging or compaction) to more stringent operations (such as incineration or vitrification). Treatment options for TRU wastes include volume reduction, solidification, vitrification, and incineration (Lakey et al. 1983). Unit costs for treatment by compaction range from $\$ 105$ to $\$ 158 / \mathrm{ft}^{3}$. Solidification costs range from $\$ 164$ to $\$ 257 / \mathrm{ft}^{3}$, while vitrification costs range from $\$ 150$ to $\$ 527 / \mathrm{ft}^{3}$. Unit costs for treatment by incineration range from $\$ 630$ to $\$ 1,050 / \mathrm{ft}^{3}$. Because it is considered best to dispose of liquid TRU waste in a solid form, a method and a medium must be developed for its immobilization. Vitrification is an acceptable method because of the advantages offered by glass as a final waste form: it has a low leach rate, has low solubility in water, has high solubility for the nuclides found in TRU, shows resistance to radiation damage, requires moderate temperatures for preparation, and has well-documented physical and chemical properties.

\subsection{STORAGE}

Since 1970, DOE has recommended that TRU waste be stored in a manner in which it can be readily retrieved in an intact, contamination-free condition. Therefore, TRU waste storage facilities were designed as safe holding areas until a permanent waste repository is established for final disposal. Typical methods for the retrievable storage of TRU waste have been to package it in plywood boxes, 55-gal drums, or metal boxes; these packages are stacked in layers on asphalt pads. The waste is then covered with plastic vinyl sheeting and overlain by up to $3 \mathrm{ft}$ of earth. Some DOE sites store TRU waste in aboveground facilities, which include warehouse-type structures, large metal storage containers, and inflatable (i.e., air-supported) buildings.

Yearly storage costs for TRU waste have been estimated at $\$ 105 / \mathrm{ft}^{3}$ for $\mathrm{CH}$ material and $\$ 1,030 / \mathrm{ft}^{3}$ for $\mathrm{RH}$ material. Figure 6 shows the actual unit cost for the receipt, handling, and burial/storage of TRU at the Hanford Site from 1985 through 1994 and the projected planning rates through 1999 . The unit burial/storage cost of $\$ 130 / \mathrm{ft}^{3}$ in 1994 is significantly lower than that of previous years, including $1993\left(\$ 265 / \mathrm{ft}^{3}\right)$. The 1994 value represents the lowest unit cost reported since 1988. This reversal of a trend of rising costs can, in part, be attributed to an increase in direct funding from DOE. This significant cost decrease contrasts sharply with the cost increase for the storage and disposal of LLW and MW at the Hanford Site. Unit costs have increased yearly because of the more stringent regulatory, safety, and operational requirements for the storage and disposal of LLW and MW. 


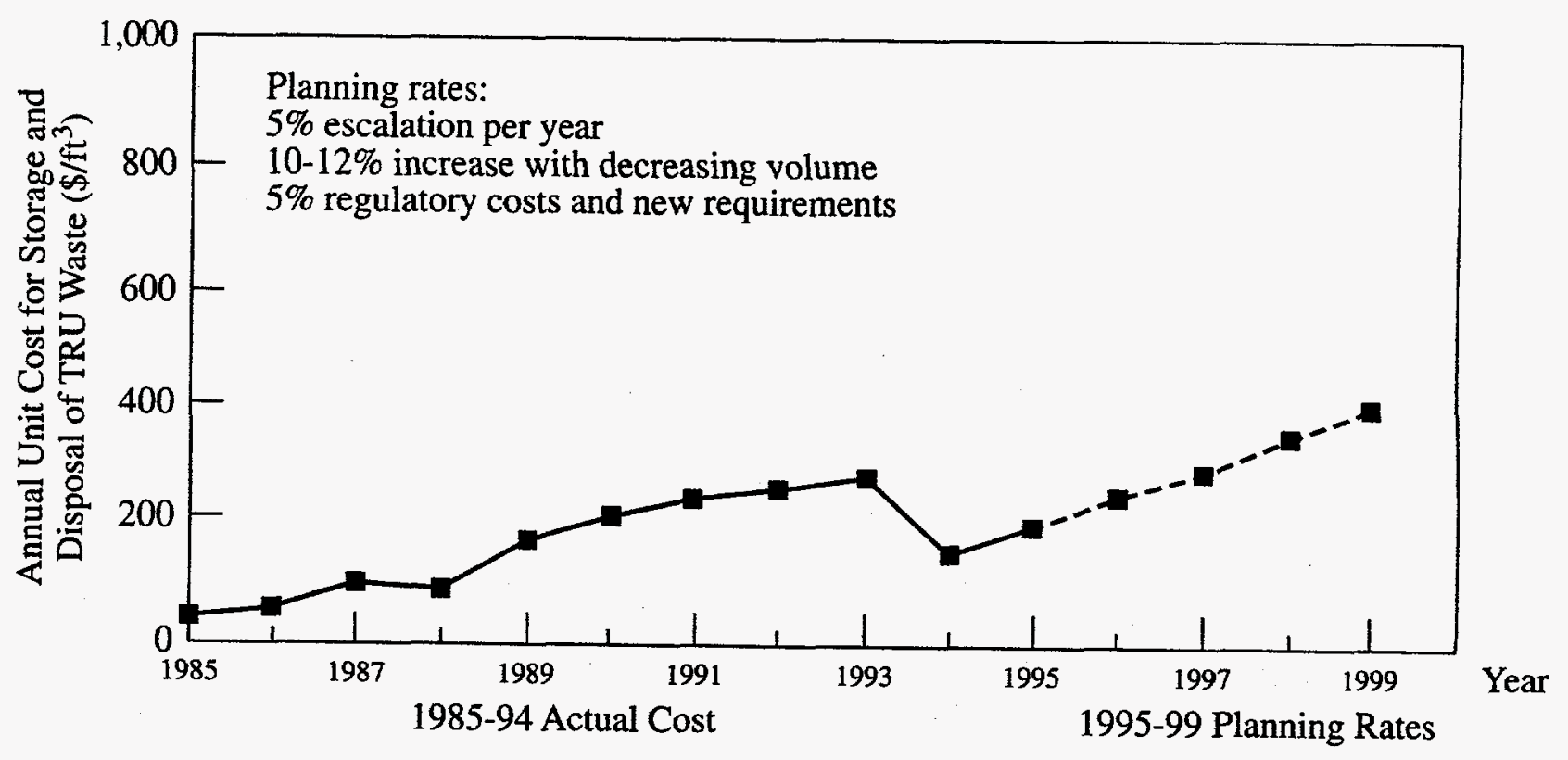

FIGURE 6 Unit Costs for Storage and Disposal of Transuranic Waste (Sources: Broomfield and Fort 1991; Hennig 1993)

The above costs are estimated on the basis of short-term, aboveground, interim storage of certified waste at the processing facility. If a longer period of interim storage is needed, storage facilities with reinforced concrete structures will have to be designed and constructed, thus increasing storage costs. Estimated yearly costs for a conceptual CH-TRU storage facility with an operating age of 20 years range from about $\$ 2,100 / \mathrm{m}^{3}$ for a facility with $10,000 \mathrm{~m}^{3}$ of capacity to about $\$ 5,100 / \mathrm{m}^{3}$ for a facility with $540 \mathrm{~m}^{3}$ of capacity (EG\&G Idaho, Inc. 1992). The CH-TRU storage facility would be a warehouse with concrete walls and a concrete roof. It would include a cleanup unit for potential spills and permanent monitoring capabilities to ensure the integrity of the stored waste containers. Estimated yearly costs for a conceptual RH-TRU storage facility with an operating age of 20 years range from about $\$ 4,800 / \mathrm{m}^{3}$ for a facility with $3,300 \mathrm{~m}^{3}$ of capacity to $\$ 3,500 / \mathrm{m}^{3}$ for a facility with $13,000 \mathrm{~m}^{3}$ of capacity (EG\&G Idaho, Inc. 1993). The RH-TRU storage facility would contain a series of shielded vaults suitable for storing wastes having high gamma radiation and requiring remote handling. The technology is similar to the modular vault dry storage technology used for long-term dry storage of SNF (see Section 5.1). The unit cost for storage of TRU waste in concrete-reinforced, above-grade, shielded facilities as a function of increasing capacity is shown in Figure 7. These data further indicate that the unit costs of interim storage for both CH-TRU and RH-TRU waste decrease with increasing storage capacity. 


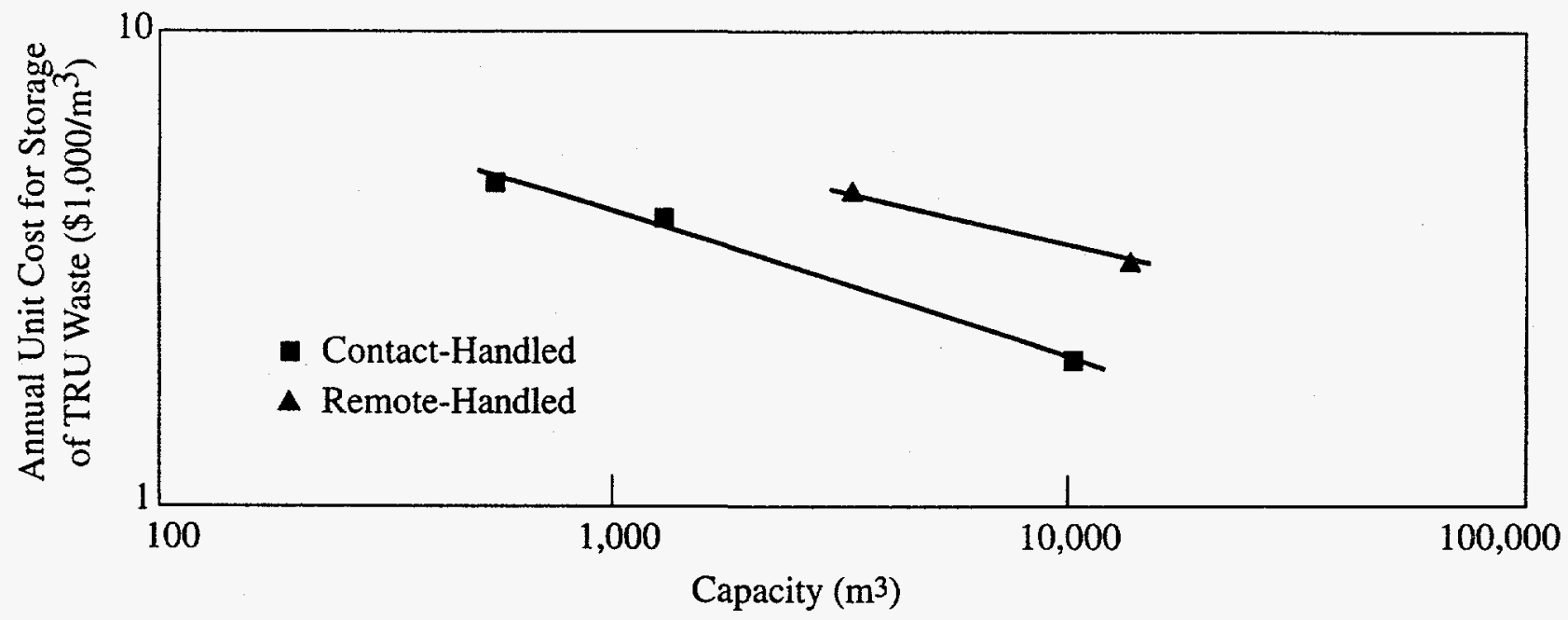

FIGURE 7 Unit Costs for Storage of Transuranic Waste in Concrete-Reinforced, Above-Grade, Shielded Facilities

\subsection{DISPOSAL}

The most common option for disposing of TRU waste has been land burial at several depths by various procedures. The estimated unit cost for disposal of TRU waste in typical shallow land trenches ranges from $\$ 98$ to $\$ 402 / \mathrm{ft}^{3}$. This option is being abandoned because of space limitations and concerns about environmental risks. Presently, the option being given serious consideration is disposal in a geologic medium. The method of deep geologic disposal constitutes a multiple-barrier approach. The wastes are placed in a stable geologic formation deep underground. The barriers are the waste packages, the disposal container, and finally the geologic medium itself.

Although the primary objective of the WIPP facility is for the study of TRU disposal, it is also the DOE facility (United Engineers and Constructors 1992) being proposed to demonstrate the safe disposal of radioactive wastes - both HLW and TRU waste. WIPP is located $25 \mathrm{mi}$ south of Carlsbad, New Mexico, in an area of 10,240 acres, of which 30 acres constitute the primary zone. The waste will be placed at a depth of approximately $660 \mathrm{~m}$ $(2,150 \mathrm{ft})$ in bedded salt. WIPP has been designed for a nominal operating life of 25 years, with the first 5 years of pilot phase operations being mostly experimental. The current design capacity of WIPP is about $1.78 \times 10^{5} \mathrm{~m}^{3}\left(6.3 \times 10^{6} \mathrm{ft}^{3}\right)$ for CH-TRU and $5,100 \mathrm{~m}^{3}$ $\left(180,000 \mathrm{ft}^{3}\right)$ for $\mathrm{RH}-\mathrm{TRU}$.

The projected unit cost for disposal of CH-TRU and RH-TRU waste in WIPP has been calculated to be about $\$ 630-\$ 780 / \mathrm{ft}^{3}$. This cost does not take into account the construction, testing, and environmental costs that could be added before the facility meets final approval. 


\subsection{TRANSPORTATION}

The CH-TRU wastes to be shipped to WIPP will be packaged in 55-gal drums, which will be placed in a TruPack (i.e., stainless-steel TRU shipping cask). A cost of $\$ 42 / \mathrm{ft}^{3}$ for shipment of CH-TRU waste to WIPP by truck was estimated in Street et al. (1992), on the basis of the following assumptions: a loaded shipment costs $\$ 4.48 / \mathrm{mi}$; the distance per shipment is 2,894 mi from Savannah River to WIPP; each shipment contains three TruPacks with 14 55-gal drums per TruPack; and each drum holds a maximum of $7.3 \mathrm{ft}^{3}$ of TRU waste.

It would be expected that transportation costs for RH-TRU waste would be more expensive than those for CH-TRU waste. Estimates of the unit transportation costs for RHTRU waste are not generally available; a cost of $\$ 1,350 / \mathrm{ft}^{3}$ for shipment of RH-TRU waste by truck has been reported.

Unit costs ranging from $\$ 0.012$ to $\$ 0.016 / \mathrm{ft}^{3}$ per mile for direct transportation to WIPP from various DOE sites (LANL, RFP, and Hanford) have been reported (Los Alamos National Laboratory 1993). The narrow range of values suggests that transport distance has a small impact on unit cost. A unit transportation cost of $\$ 0.015 / \mathrm{ft}^{3}$ per mile can be estimated on the basis of the previously reported unit cost of $\$ 42 / \mathrm{ft}^{3}$ per mile for Savannah River. 


\section{HAZARDOUS WASTE}

Hazardous waste (HAZW) is defined in the Resource Conservation and Recovery Act (RCRA) of 1976 as a nonradioactive solid waste or a combination of solid wastes that, because of its quantity, concentration, or physical, chemical, or infectious characteristics, may cause or significantly contribute to an increase in mortality or an increase in serious, irreversible, or incapacitating reversible illness or pose a substantial present or potential hazard to human health or the environment when improperly treated, stored, transported, disposed of, or otherwise managed (U.S. Environmental Protection Agency 1986). Waste must meet two criteria to be classified as hazardous. It must be solid and it must be hazardous. For this definition of HAZW, waste is considered solid if it is in the form of a liquid, solid, semisolid, or contained gas. Solid waste is considered hazardous if it exhibits one of the primary characteristics of HAZW - such as ignitability, reactivity, corrosibility, or measurable toxicity.

Improper disposal of HAZW is one of the most pressing environmental problems in this country. Estimates indicate that 59 million tons of HAZW is generated annually. The chemical industry accounts for more than $35 \%$ of waste generated, followed by the petroleum and primary metals industries (Evans 1989).

Methods for treating HAZW include physical, chemical, and biological techniques to remove or change its toxic properties (Pace et al. 1992). In biological treatment, a variety of microorganisms break down organic and toxic materials into water, carbon dioxide, and other nontoxic matter. Physical and chemical processes are used to treat both inorganic and organic HAZW that is nonbiodegradable or resistant to biodegradation (Cashman 1986).

\subsection{TREATMENT}

Costs for treating HAZW range from $\$ 42$ to $\$ 105$ per ton for bulk treatment or from $\$ 130$ to $\$ 320$ per 55-gal drum (Donnachie 1991). Sorption and solidification processes have established success rates. Stabilization and fixation processes for inorganic and HM wastes have also proven successful, establishing these processes as acceptable technologies for landbanned restricted wastes. Stabilization of organic wastes has had a varying degree of success, so there is general agreement that this treatment of organic wastes should be handled on a case-by-case basis. The cost of treatment depends on the type and size of the treatment process and the characteristics of the waste. Furthermore, treatment costs increase as the influent waste concentrations increase.

\subsection{STORAGE}

Hazardous waste is usually put in interim, short-term storage in above-grade facilities, at an annual cost of $\$ 8$ per pound for solid HAZW and $\$ 4$ per gallon for liquid HAZW. 


\subsection{DISPOSAL}

Existing technologies and methods for disposing of HAZW include fuel blending of chemical wastes, land disposal, incineration, acid-base neutralization, oil and solvent recovery, and cyanide detoxification (Erdogan 1988). In evaluating the various options for disposing of HAZW, a major consideration is whether to reuse or recycle the material (Gunnerson and Jones 1984). Rather than being discarded or incinerated, solvents are reclaimed, usually through blending, distillation solvent extraction, and evaporation. Chemicals that cannot be reused or recycled are incinerated, if possible, or buried in a chemical landfill. On the basis of these considerations, incineration is the most expensive HAZW disposal option, costing from $\$ 53$ to $\$ 530$ per ton for on-site incineration. Incineration of dioxin-contaminated soils has been estimated to cost $\$ 790$ per ton, and incineration of materials contaminated with polychlorinated biphenyls at concentrations greater than 25,000 parts per million costs from $\$ 950$ to $\$ 1,740$ per ton (see Table 1 ).

Incineration is the ideal technique for disposing of HAZW containing solvent and organic materials. This high-temperature destruction technique can burn nearly any combustible liquid organic waste. The unit residue may be disposed of in a chemical landfill. This process has the following advantages: it reduces the weight and volume of the waste and it recovers heat energy (Theodore and Reynolds 1988; Star 1985; Vogel and Martin 1984).

For HAZW that cannot be reused, recycled, or incinerated, the most economical option is to dispose of it in chemical landfills. Typical unit costs range from $\$ 26$ to $\$ 260$ per ton for disposal of drummed, bulk, and sludge wastes. Disposal in landfills of waste that is highly hazardous can cost as much as $\$ 320$ per ton. However, pretreatment techniques can be used to make a particular waste stream more amenable to landfill disposal.

Unit costs for fuel blending and solvent and oil recovery, the most economical disposal options, range from $\$ 63$ per 55-gal drum (minimum of 50 drums) for fuel blending to $\$ 126$ per 55 -gal drum (minimum of 50 drums).

\subsection{TRANSPORTATION}

Costs for transporting HAZW range from $\$ 2.37$ to $\$ 2.90$ per mile for moving 1 to 20 55-gal drums by truck for a one-way distance of $500 \mathrm{mi}$. 


\section{MIXED WASTE}

Mixed waste (MW) is low-level radioactive waste that also contains a hazardous component. Treatment, storage, and disposal of MW must satisfy the requirements for both LLW and HAZW unless the MW can be treated or there is a reason for it to fall under one set of requirements.

Currently, generic characterization of MW is difficult for several reasons: (1) MW is made up of different blends of hazardous (chemical and/or physical) and radioactive components that dictate precautionary measures, (2) several processes can be involved in generating MW, (3) various methods are used to prepare MW for storage, and (4) new regulations regarding toxicity characterization and leaching properties have recently been adopted.

The total inventory of DOE MW through 1991, which included contributions from 28 sites, was $1.014 \times 10^{6} \mathrm{~m}^{3}$. The total amount of DOE MW generated in 1991, which included contributions from 32 sites, was $6.605 \times 10^{4} \mathrm{~m}^{3}$.

Recently, the NRC and EPA cosponsored a survey to compile a national profile of the volumes, characteristics, and treatability of commercially generated MW (U.S. Nuclear Regulatory Commission 1992). Data from the survey indicate that in 1990 , about $3,950 \mathrm{~m}^{3}$ of MW was generated in the United States, $72 \%$ of which consisted of liquid scintillation fluids and the remainder of which consisted of oils, nonbiodegradable organics, and corrosive wastes. The study also concluded that approximately $13 \%$ of this $3,950-\mathrm{m}^{3}$ total cannot be treated by existing technologies.

\subsection{TREATMENT}

Facilities and technologies are being designed and tested to treat and process a broad range of the aqueous and organic liquid and solid $\mathrm{MW}$ and alpha-emitting mixed waste ( $\alpha \mathrm{MW}$ ) now being stored. MW, like LLW, is first sorted and then undergoes either chemical and thermal treatment, separation, and concentration, and/or size and volume reduction. The cost of treatment varies from a low of $\$ 26 / \mathrm{ft}^{3}$ for shredding and compaction (volume reduction factor of $10: 1$ ), to $\$ 1,110 / \mathrm{ft}^{3}$ for incineration (volume reduction factor of $50-200: 1$ ), to $\$ 1,480 / \mathrm{ft}^{3}$ for metal melting. The higher values for each selected treatment option shown in Table 6 represent the unit costs of treatment for a facility with a small throughput capacity; the lower values represent those costs for a facility with a larger throughput capacity (in general, 10 times larger). In all cases, treating $\alpha \mathbf{M W}$ is more expensive than treating $\mathbf{M W}$ because the alpha-contaminated wastes require remote handling to minimize health, safety, and environmental concerns. 


\subsection{STORAGE}

Yearly costs for storing MW, primarily in shallow land trenches for short periods before disposal, are estimated to be $\$ 31 / \mathrm{ft}^{3}$ for solids and $\$ 118 /$ gal for liquids.

\subsection{DISPOSAL}

Costs for disposing of $\mathrm{MW}$ in shallow land trenches vary from $\$ 230 / \mathrm{ft}^{3}$ for compacted waste to $\$ 290 / \mathrm{ft}^{3}$ for incinerated wastes. The cost for disposing of nonincinerated and noncompacted materials can be as high as $\$ 658 / \mathrm{ft}^{3}$ (Street et al. 1992). Figure 8 shows the actual unit cost for storage and disposal of MW at the Hanford Site through 1994 and the projected planning rates through 1999.

\subsection{TRANSPORTATION}

Costs for transporting MW by truck range from $\$ 2.37$ to $\$ 2.90$ per mile for 1 to 20 55-gal drums for a one-way distance of $500 \mathrm{mi}$.

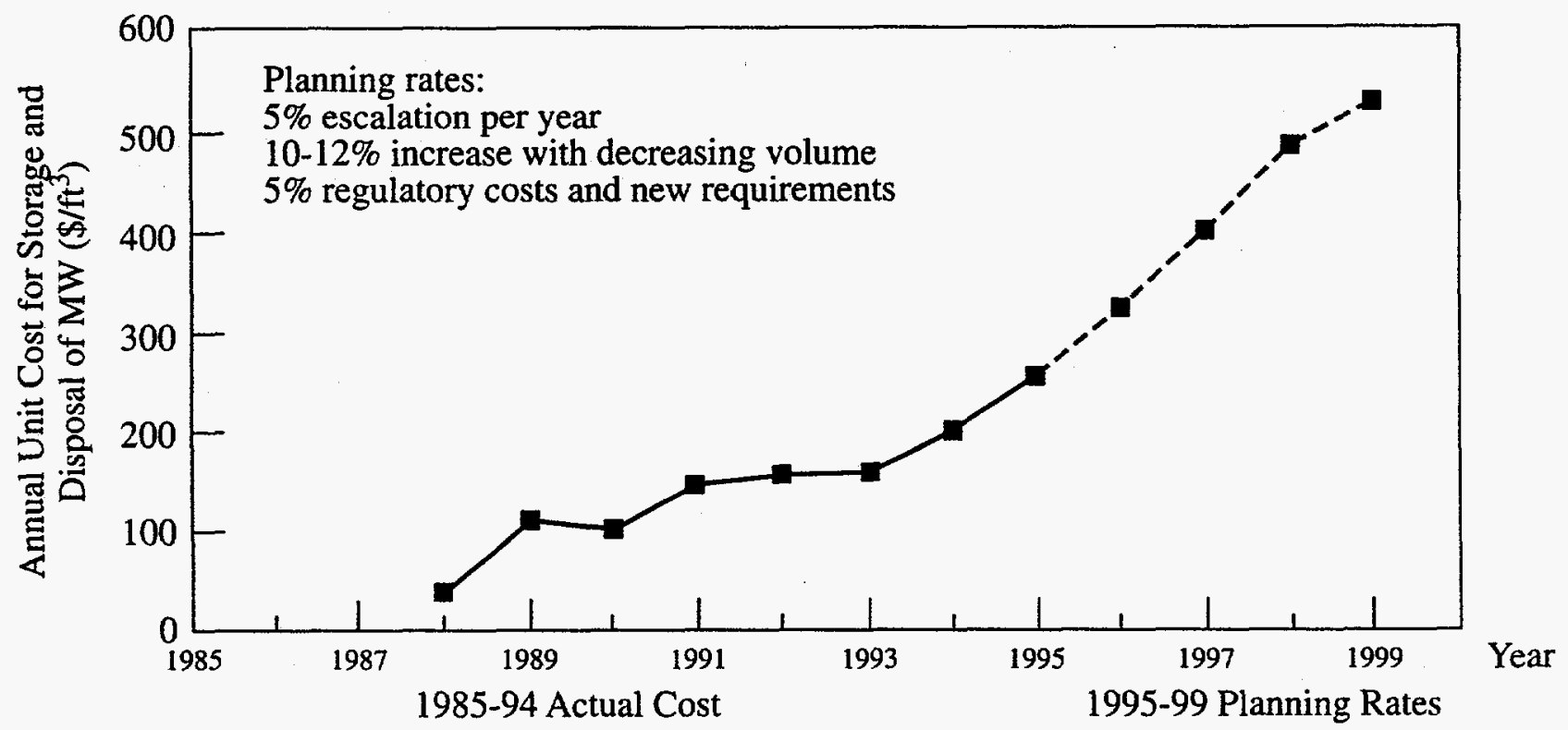

FIGURE 8 Unit Costs for Storage and Disposal of Mixed Waste (Sources: Broomfield and Fort 1991; Hennig 1993) 


\section{SANITARY WASTE}

Sanitary waste (SW) is nonradioactive and nonhazardous waste that is ultimately disposed of in a sanitary landfill. Typical examples of SW from nuclear facilities are shop and construction debris, cafeteria trash, and general office trash. A typical nuclear facility will generate approximately 40 tons/d of SW to be disposed in a landfill. On the basis of 260 "receipt days" per year, the facility's annual SW generation and disposal rate is 10,400 tons. It is assumed that the SW production rate is typically $38 \mathrm{~m}^{3}$ per person per year.

\subsection{TREATMENT}

Sanitary waste is usually taken directly to the landfill for disposal, without having received any treatment or having been put in interim storage. However, in some cases, the SW is compacted to reduce its volume. This treatment costs $\$ 21$ to $\$ 320 /$ ton, depending on the degree of volume reduction. Usually volume reduction factors of 2 to 20 are realized.

\subsection{DISPOSAL}

Landfilling is currently the most common means for disposing of SW. A typical disposal or tipping fee is $\$ 32 /$ ton (Wehran Envirotech 1992); however, the fee varies widely from region to region. There have recently been discussions about whether this fee reflects the true cost of SW disposal, and efforts have been directed toward quantifying the costs of the environmental and social impacts of landfills (Hirshfeld 1989). Physical impacts on the environment are caused by the natural generation of release products, particularly leachate and landfill gas. Social impacts are reflected in adjacent property depreciation and land opportunity costs. Land opportunity costs have two components, one related to the landfill site and the other to surrounding properties. On the basis of considering all these other impacts, the tipping fee may be as high as $\$ 70 /$ ton.

As recycling has become more popular, material recovery facilities (MRFs) have been designed and operated. These facilities separate commercial recyclable products (bottles and cans) and prepare them as well as several grades of paper for shipment to end-user markets (National Solid Waste Management Association 1993). The average cost for processing recyclable products at an MRF (before revenues from the sale of these products are considered) is $\$ 53 /$ ton, with a range from $\$ 30$ to $\$ 82.2 /$ ton. Paper costs $\$ 35.3 /$ ton on average to process, considerably less than "commingled" recyclables, which cost $\$ 87.8 /$ ton on average. Newspaper is also one of the least expensive items to process, averaging $\$ 35.4 /$ ton.

Plastic is the most expensive of the typical recyclable products to process; costs average $\$ 193.6 /$ ton for polyethylene and $\$ 197.9 /$ ton for high-density polyethylene. The greatest range of processing costs occurs for aluminum cans, from $\$ 76.7$ to $\$ 381.8 /$ ton (a difference of $\$ 305 /$ ton). This large difference may be caused by low tonnages or above-average labor costs for specific regions. Any MRF with an unusually high processing 
cost can skew the average cost. In the case of aluminum cans, eliminating the high and low MRF processing costs lowers the average processing cost from $\$ 151$ to $\$ 131.4 /$ ton.

\subsection{TRANSPORTATION}

The hourly cost to transport SW by truck to the landfill ranges from $\$ 63$ to $\$ 105$. This figure includes the labor and equipment costs associated with the transport vehicles. An hourly cost of $\$ 89.5$ has been reported for on-site shipment of SW at SRS; on the basis of a unit transportation time of $0.005 \mathrm{~h} / \mathrm{ft}^{3}$, this hourly rate translates into a unit cost of $\$ 0.45 / \mathrm{ft}^{3}$. 


\section{SUMMARY AND CONCLUSIONS}

This report tabulates and summarizes data needed to estimate the unit costs for the treatment, storage, disposal, and transport of spent nuclear fuel and high-level radioactive, low-level radioactive, transuranic radioactive, hazardous, mixed (low-level radioactive plus hazardous), and sanitary wastes, from the time they are generated to their final disposition and institutional control. It discusses the nature, origin, and categories of radioactive waste and provides an overview of radioactive waste management and its economics. Tables 1-7 present representative unit costs for the different operations for each waste type. Key factors that influence unit costs are identified and discussed in Sections 5 through 11.

The variations in the unit costs for many operations and waste types can, in part, be attributed to the fact that different percentages of the various cost inputs are apportioned to establish the final unit cost. For example, capital cost is basically the cost of purchasing and installing equipment. The purchasing cost is generally a firm cost. The installation cost, however, can vary, depending on the geographic location, regulatory requirements for control devices, and local cost of labor and materials. Operating and maintenance costs can vary from site to site because these costs partly reflect local conditions (such as staffing requirements and practices) and local labor and utility costs.

Various levels of refinement are possible in estimating unit costs, depending on the purpose of the estimate and level of completeness of the input data. In addition to basic data on waste type and volume, additional input data required can include data on waste activity concentrations $\left(\mathrm{Ci} / \mathrm{tt}^{3}\right)$, extent of volume reduction employed, distances between the generating site and burial site, specific burial site to be used, and mode of transport and containment, as well as information on whether the waste will be stored on-site for some interim period before being permanently disposed of.

The treatment cost depends strongly on the method chosen (Gimpel 1992). Solidification of waste in cement is generally perceived as the most economical and practical treatment method for LLW and MW; however, it increases the final volume of waste to be disposed of by $30-50 \%$. Vitrification of waste in glass is generally considered to be a more expensive but more effective treatment method, since it substantially reduces the final volume of waste (volume reduction factor of 10-40:1) for disposal. In this context, vitrification may be a less expensive treatment option than solidification.

Storage and disposal costs, assessed on a per-unit-volume basis (i.e., $\$ / \mathrm{ft}^{3}$ ), are strongly influenced by the specific characteristics of the waste (i.e., contaminated equipment that has not been reduced in volume). Disposal costs, in many cases, share the cost for interim storage because of the shortage of burial facilities or processing surges. The transportation cost depends strongly on the nature of the waste, packaging requirements for transport, mode of transport, and distance.

Waste characterization and sampling methods should be given special consideration, since it has been established they have a major impact on unit costs. 
Consideration should also be given to newer, developing technologies that could influence long-term waste management strategies and thereby influence unit costs. Up-to-date cost analyses of such developing technologies should be a component of any assessment.

Technical and engineering considerations that influence the design of a particular treatment, storage, and disposal facility can be unique. Cost, however, is a consideration that is relevant to all systems. Cost is especially important in cases where different technologies can be used to achieve the same objective. In many cases, cost is the basis for determining which technology is the best from among the alternatives that are available. The unit costs of waste operations must be updated periodically because of changes in technology, environmental regulations, waste forecasts, and operating costs (GAO 1992b, 1993). 


\section{REFERENCES}

Albuquerque Field Office, 1991, Environmental Restoration and Waste Management Five-Year Plan, Activity Data Sheet 1002-C1, U.S. Department of Energy, Albuquerque, N.M., Sept. 6. American Nuclear Society, 1986, "Waste Management," Nuclear News 29(3):84, Mar.

Argonne National Laboratory, 1993, Institutional Plan FY 1994-FY 1999, fiscal year 1993 budget data, Argonne, Ill., Sept.

Battelle Nuclear Systems Group, 1989, Recommended Regular and Dedicated Rail Handling Costs for Estimating Costs of Spent Fuel and High-Level Waste Shipments, Columbus, Ohio.

Belter, W.G., 1963, "Present and Future Programs in the Treatment and Ultimate Disposal of HLW in U.S.A.," in Treatment and Storage of HLWs, proceedings of the Symposium on Treatment and Storage of HLWs, International Energy Agency, Vienna, Austria.

Bixby, W.W., 1987, "DOE's Program for Transportation of Civilian HLW - An Overview," in proceedings of the 27th Annual Meeting of the Institute of Nuclear Materials Management, New Orleans, La.

Broomfield, B.J., and L.A. Fort, 1991, Assessment of High-Temperature Thermal Process to Treat Mixed Waste at the Hanford Site, WHC-SA-1044, Westinghouse Hanford Co., Richland, Wash., May.

Callagher, E.F., 1988, "DOE Procurement Activities for Spent Fuel Shipping Costs," Journal of Nuclear Materials Management 16(3):125-130.

Cashman, J.R., 1986, Management of Hazardous Waste - Treatment (Storage) Disposal Facilities, Technomic Publishing Co., Lancaster, Penn.

Choi, A.S, and J.R. Fowler, 1990, Material Balance Tables for the DWPF Basic Data Report, WSRC-TR-90-93, rev. 138, Westinghouse Savannah River Company, Aiken, S.C., Feb. 28.

DOE: See U.S. Department of Energy.

Donnachie, R., 1991, "The Effects of Land Ban Restrictions: On-Site Off-Site Economics," Pollution Engineering 23(10):59-65, Oct.

Duffy, J.I., 1983, Treatment, Recovery, and Disposal Processes for Radioactive Wastes, Recent Advances, Noyes Data Corp., Park Ridge, N.J.

Eberhardt, L.I., et al., 1986, Survey of Statistical and Sampling Needs for Environmental Monitoring of Commercial Low-Level Radioactive Waste Disposal Facilities, NUREG/CR-4152, Nuclear Regulatory Commission; also PNL-4804, Pacific Northwest Laboratory, Richland, Wash. 
EG\&G Idaho, Inc., 1987, Alternative Concepts for Low-Level Radioactive Waste Disposal, Idaho Falls, Id.

EG\&G Idaho, Inc., 1992, Waste Management Facilities Cost Information (WMFCI) Attachments, EGG-WTD-10443, Idaho Falls, Id., Sept.

EG\&G Idaho, Inc., 1993, Waste Management Facilities Cost Information Estimating Data for Greater-Than-Class C and DOE Equivalent Special Case Waste, EGG-WM-10709, Idaho Falls, Id., July.

English, M.R., 1991, The Economic and Social Impacts of Chem-Nuclear Low-Level Waste Disposal Facility at Barnwell, S.C., University of Tennessee, Knoxville, Tenn.

Electric Power Research Institute, 1988a, Radioactive Waste Volume Reduction and Solidification, EPRI-NP-5958, Palo Alto, Calif.

Electric Power Research Institute, 1988b, Advanced Radioactive Compaction Techniques, EPRI-NP-5838, Palo Alto, Calif.

Erdogan, H., 1988, "Cost Estimates for Several Hazardous Waste Disposal Options," in Hazardous Waste and Hazardous Materials, Mary Ann Liebert, Inc., Publishers, New York, N.Y.

Evans, G.M., 1989, Standard Handbook of Hazardous Waste Treatment and Disposal: Cost Perspective for Hazardous Waste Management, H.M. Freeman (editor), McGraw-Hill Book Co., New York, N.Y.

Feizollahi, F., and D. Shropshire, 1992, Waste Management Facilities Cost Information Report, EGG-WTD-10443, EG\&G Idaho, Inc., Idaho Falls, Id., Oct.

Feizollahi, F., and D. Shropshire, 1993, Waste Management Facilities Cost Information Report for Spent Nuclear Fuel, EGG-WM-10670, EG\&G Idaho, Inc., Idaho Falls, Id., Mar.

Flower, W., 1992, personal communication from Waste Management Corp., Oak Brook, Ill. to W. Kisieleski, Argonne National Laboratory, Argonne, $\mathrm{Ill}$.

Fountes, C.E., 1991, "Economic Aspects of EPA's HLW Draft Proposed Regulation," Waste Management $9(2): 78-81$.

Frei, M.W., 1992, personal communication from U.S. Department of Energy, Office of Waste Management Projects, Washington, D.C., to J. Schultz, U.S. Government Accounting Office, Washington, D.C., May 13.

GAO: See U.S. General Accounting Office.

Garner, G.L., 1989, "Concrete Casks for On-Site Dry Storage of Spent Fuel," Transactions of the American Nuclear Society 60:120. 
Geer, G., 1992, personal communication from Commonwealth Edison, Zion Station, Zion, Ill., to W. Kisieleski, Argonne National Laboratory, Argonne, Ill.

Gimpel, R.F., 1992, Solidification and Vitrification Life-Cycle Economics Study, FEMP-2249A, Fernald Environmental Management Project, Fernald, Ohio, Jan. 24.

Godlewski, N.Z., 1987, "Spent Fuel Storage — An Update," Nuclear News 30(3):47.

Gunnerson, C.G., and D.C. Jones, 1984, "Costing and Cost Recovery for Waste Disposal and Recycling," Waste Management and Research 2(2):107-118.

Hanrahan, T., 1991, "Economic Analysis of LLRW Disposal Compact Progress," Waste Management 9(2):467-474.

Harrison, J., 1992, personal communication from Chem Nuclear Systems, Inc., Channahon, IIl., to W. Kisieleski, Argonne National Laboratory, Argonne, Ill.

Hench, L.L., et. al 1984, "HLW Immobilization Forms," Nuclear Chemical Waste Management 5(1):149-173.

Hennig, J.M., 1993, Fiscal Year 1994 Rates for Disposal and Storage of Radioactive Solid Waste at the Hanford Site, memorandum from U.S. Department of Energy, Richland Operations Office, Washington, to distribution, Dec. 8.

Hirshfeld, S.S., 1989, Assessing the True Cost of Landfills, M.S. thesis, Duke University, Durham, N.C.

International Atomic Energy Agency, 1991, Guidebook on Spent Fuel Storage, 2nd ed., Technical Reports Series 240, Vienna, Austria.

Jacobs, M.H., et al., 1984, Low-Level Radwaste Economics, EPRI NP-3577, Electric Power Research Institute, Palo Alto, Calif.

Jensen, R.T., 1983, "Inventions and Characteristics of Transuranic Waste," Nuclear Chemical Waste Management 4(1):19-24.

Johnson, E.R., 1990, "Choosing At-Reactor Spent Fuel Storage Technologies," in Proceedings of the International Topical Meeting, High Level Radioactive Waste Management, vol. 2, Las Vegas, Nev., Apr. 8-12.

Kalb, P.D., and M. Fuhrmann, 1992, Polyethylene Encapsulation of Single-Shell Tank Low-Level Wastes, Annual Progress Report, BNL-52365, Brookhaven National Laboratory, Upton, N.Y.

Kendrick, R., 1992, personal communication from Bio-Waste Trucking Co., Raleigh, N.C., to W. Kisieleski, Argonne National Laboratory, Argonne, $\mathrm{Ill}$. 
Klepfer, H.H., and R.W. Bowser, 1991, "Rancho Seco Spent Fuel Disposition Strategy," in Proceedings of the Second Annual International Conference, High Level Radioactive Waste Management, vol. 1, Las Vegas, Nev., Apr. 28- May 3.

Lakey, L.T., et al., 1983, "Management of Transuranic Waste throughout the World," Nuclear Chemical Waste Management 4(1):35-46.

Lilly, J., 1986, Investigation of Rail Shipping Costs for Spent Nuclear Fuel, prepared by Roy F. Weston Consultants, Inc., Washington, D.C., for U.S. Department of Energy, Washington, D.C.

Los Alamos National Laboratory, 1993, Avoidable Waste Management Costs at DOE Facilities, LA-UR-93-1154, Los Alamos, N.M., Mar. 29.

Macbeth, P.J., et al., 1979, Evaluation of Alternative Methods for the Disposal of Low-Level Radioactive Waste, NUREG/CR-0680, U.S. Nuclear Regulatory Commission, Washington, D.C.

McCartney, J.S., and R.B. Cairns, 1984, Cost Comparisons for On-Site Spent Fuel Storage Options, EPRI-NP-3380, Electric Power Research Institute, Palo Alto, Calif.

McDonell, W.R., 1986, Economic Analysis of Projected High-Level Waste Immobilization Operations at the Savannah River Plant, DP-MS-86-92, Sept.

McNair, G.W., et al., 1986, Truck and Rail Changes for Shipping Spent Fuel and Nuclear Waste, PNL-5797, Pacific Northwest Laboratory, Richland, Wash.

National Solid Waste Management Association, 1993, Special Report - The Cost to Recycle at a Material Recovery Facility, Washington, D.C.

Pace, R.S., et al., 1992, "Cost Modeling for Environmental Compliance," in proceedings of the Conference on Federal Environmental Restoration, Vienna, Va., Apr. 15-17.

Rasmussen, B., 1988, "The Dry Storage Option for Spent Fuel Management," Transactions of the American Nuclear Society 52:73; also presented at the Fuel Cycle Conference, New Orleans, La., Apr. 10-13.

Roles, J.W., 1990, Characteristics of Low-Level Radioactive Waste Disposal during 1987 through 1989, NUREG-1418, U.S. Nuclear Regulatory Commission.

Richards, L.M., and M.J. Szulinski, 1979, "Subsurface Storage of Commercial Spent Fuel," Nuclear Technology 43:155.

Rod, S.R., 1991, Cost Estimates of Operating On-Site Spent Fuel Pools after Final Reactor Shutdown, PNL-7778, Pacific Northwest Laboratory, Richland, Wash., Aug.

Sire, D.L., et al., 1992, ICPP Special Fuels Canning and Characterization Facility, WINCO-1093, Westinghouse Idaho Nuclear Company, Inc., Idaho Falls, Id., Apr. 
Sivill, T.E., et al., 1993, "Use of Life-Cycle Cost Estimates in the Evaluation of Proposed Waste-Treatment Facilities," in proceedings of the Symposium on Waste Management, Tucson, Ariz., Feb. 28-Mar. 4.

Smith, R., 1992, personal communication from Green Valley Landfill, Downers Grove, Ill., to W. Kisieleski, Argonne National Laboratory, Argonne, Ill.

Star, A.M., 1985, "Cost Estimating for Hazardous Waste Incineration," Pollution Engineering 17(4):58-63.

Stelluto, J.D., 1991, LLW Is a Technical Issue, Waste Management, Tucson, Ariz., Feb.

Street, G.H., et al., 1992, SRS Waste Cost Analysis, WSRC-RP-92-631, Westinghouse Savannah River Co., Aiken, S.C.

Tang, Y.S., and J.H. Saling, 1986, "Options for Increasing Spent Fuel Storage Capacity," in proceedings of the American Nuclear Society First Regional Conference, Pittsburgh, Penn.

Tang, Y.S., and J.H. Saling, 1990, "Storage" and "Transportation," in Radioactive Waste Management, Hemisphere Publishing Corp., New York, N.Y.

Theodore, J., and J. Reynolds, 1988, Introduction to Hazardous Waste Incineration, Wiley Interscience, New York, N.Y.

United Engineers and Constructors, 1992, United Engineers and Constructors Waste Receiving and Processing Facility Module 1: Preliminary Design Report, DOE/R1/11946-1, U.S. Department of Energy, Washington, D.C.

U.S. Congress, 1983, Nuclear Waste Policy Act of 1982, Public Law 97-425, Jan. 7.

U.S. Department of Commerce, 1994, Survey of Current Business 74(1):21, Washington, D.C., Jan.

U.S. Department of Energy, 1983, The Defense Waste Management Plan, DOE/DP-0015, Washington, D.C.

U.S. Department of Energy, 1984, Projections of U.S. Nuclear Plant Capacity Generation and Spent Fuel Discharge, 1984-2020, SR-NAFD-84-1, U.S. Energy Information Administration, Washington, D.C.

U.S. Department of Energy, 1985, Spent Fuel Storage Requirements, DOE/RL-85-2, Washington, D.C.

U.S. Department of Energy, 1986a, Perspective on Methods to Calculate a Fee for Disposal of Defense High-Level Waste in Combined (Civilian/Defense) Repositories, DOE/RL-86-10, Washington, D.C. 
U.S. Department of Energy, 1986b, Transportation Business Plan, DOE/RW-0046, Washington, D.C.

U.S. Department of Energy, 1987a, Defense Waste Management Plan for Buried TRU - Contaminated Waste, TRU - Contaminated Soil, and Difficult-to-Certify TRU Waste, DOE/DP-0044, Washington, D.C.

U.S. Department of Energy, 1987b, OCRWM Mission Plan Amendment, DOE/RW-0128, Office of Civilian Radioactive Waste Management, Washington, D.C.

U.S. Department of Energy, 1987c, Final Environmental Impact Statement - Disposal of Hanford Defense High-Level, Transuranic, and Tank Wastes, DOE/EIS-0113, vol. 2, Dec.

U.S. Department of Energy, 1988a, Long Range Master Plan for Defense TRU Program, DOE/WIPP 88-028, Carlsbad, N.M.

U.S. Department of Energy, 1988b, Transporting Spent Fuel - An Overview, DOE/RW-0065, Washington, D.C.

U.S. Department of Energy, 1989a, Final Version of Dry Cask Storage Study, DOE/RN-0020, Washington, D.C.

U.S. Department of Energy, 1989b, Monitored Retrievable Storage Submission to Congress, Volume II, Environmental Assessment for a Monitored Retrievable Storage Facility, DOE/RW-0035/1, Washington, D.C., Feb.

U.S. Department of Energy, 1990a, Analysis of the Total-System Life Cycle Cost for the Civilian Radioactive Waste Management Program, DOE/RW-0295, Office of Civilian Radioactive Waste Management, Washington, D.C.

U.S. Department of Energy, 1990b, Estimates of the Total-System Life-Cycle Cost for the Restructured Program: An Addendum to the May 1989 Analysis of the Total-System Life Cycle Cost for the Civilian Radioactive Waste Management Program, DOE/RW-0295P, Office of Civilian Radioactive Waste Management, Washington, D.C.

U.S. Department of Energy, 1991a, Environmental Restoration and Waste Management (EM) Program, Five-Year Plan, Fiscal Years 1993-1997, DOE/S-0089P, Office of Environmental Restoration and Waste Management, Washington, D.C., Aug.

U.S. Department of Energy, 1991b, Environmental Restoration and Waste Management (EM) Program, An Introduction, DOE/EM-0013P, Washington, D.C., June.

U.S. Department of Energy, 1991c, Transportation System Data Base, Reference Transportation Data for the Civilian Radioactive Waste Management Program, rev. 1, Washington, D.C., Apr. 
U.S. Department of Energy, 1992a, Integrated Database for 1992: Spent Fuel and Radioactive Waste Inventories, Projections, and Characteristics, DOE/RW-0006, rev. 8, Office of Civilian Radioactive Waste Management and Office of Environmental Restoration and Waste Management, Washington, D.C., Oct..

U.S. Department of Energy, 1992b, Report on Pricing Options for Waste Management Systems, Charge-Back Financial Working Group, Washington, D.C., June 25.

U.S. Environmental Protection Agency, 1986, RCRA Orientation Manual, EPA 530/SW-86001, Washington, D.C., Jan.

U.S. Environmental Protection Agency, 1990, Control Cost Manual, EPA 450/3-90-006, 4th ed., Washington, D.C., Sept.

U.S. General Accounting Office, 1992a, Independent Technical Review of the Hanford Tank Farm Operations, GAO/RCED-92-99, Washington, D.C., March.

U.S. General Accounting Office, 1992b, Defense Waste Processing Facility - Cost, Schedule, and Technical Issues, GAO/RCED-92-183, Washington, D.C., June.

U.S. General Accounting Office, 1993, Hanford Tank Waste Program Needs Cost, Schedule, and Management Changes, GAO/RCED-93-99, Washington, D.C., Mar.

U.S. Nuclear Regulatory Commission, 1988, Generic Cost Estimates for the Disposal of Radioactive Wastes, NUREG/CR-4555, rev. 1, Washington, D.C., Sept.

U.S. Nuclear Regulatory Commission, 1992, National Profile on Commercially Generated LowLevel Radioactive Mixed Waste - Technical Letter Report, FIN L-16470, prepared by Oak Ridge National Laboratory, Oak Ridge, Tenn., for U.S. Nuclear Regulatory Commission and U.S Environmental Protection Agency, June 19.

Vogel, G.A., and E.J. Martin, 1984, "Hazardous Waste Incineration, Part 4 - Estimating Operating Costs," Chemical Engineering 91(3):97-100, Jan. 9.

Wehran Envirotech, 1992, Northeast Illinois Landfill Tipping Fee Survey for Solid Waste, 5th annual report, Chicago, Ill.

Wiemers, K.D., 1992, Preliminary Assessment of Candidate Immobilization Technologies for Retrieved Single-Shell Tank Wastes, PNL-7918, Pacific Northwest Laboratory, Richland, Wash.

Williams, R.F., 1983, Low-Level Waste Management Strategies, Atomic Industrial Forum, Kansas City, Kan.

Wolfe, R.A., 1976, An Identification of the Waste Generated within the Nuclear Fuel Cycle, AICHE Symposium Series 154, vol. 72.

Zacha, N.J., 1988, "Fuel Rod Consolidation," Nuclear News 31(3):68. 